\title{
The Decreased Popularity of the Teaching Sector in the 1970s
}

\author{
Steingrimsdottir, Herdis
}

Document Version

Accepted author manuscript

Published in:

Economics of Education Review

DOI:

10.1016/j.econedurev.2019.101948

Publication date:

2020

License

CC BY-NC-ND

Citation for published version (APA):

Steingrimsdottir, H. (2020). The Decreased Popularity of the Teaching Sector in the 1970s. Economics of Education Review, 74, [101948]. https://doi.org/10.1016/j.econedurev.2019.101948

Link to publication in CBS Research Portal

\section{General rights}

Copyright and moral rights for the publications made accessible in the public portal are retained by the authors and/or other copyright owners and it is a condition of accessing publications that users recognise and abide by the legal requirements associated with these rights.

Take down policy

If you believe that this document breaches copyright please contact us (research.lib@cbs.dk) providing details, and we will remove access to the work immediately and investigate your claim. 


\title{
The Decreased Popularity of the Teaching Sector in the 1970s
}

\author{
Herdis Steingrimsdottir*
}

\begin{abstract}
In the 1970s, the proportion of male college freshmen who planned to become teachers dropped from $15 \%$ to $3 \%$, and that of female freshman from $45 \%$ to $12 \%$. In this paper, I use nationally representative survey data on the career plans of college freshmen to look at the roles played by increased access to fertility controls and the unionization of the teaching sector, in the decline in the popularity of the teaching sector during this period. I find that the overall impact of these factors on men was small and insignificant, whereas early legal access to contraceptives increased women's likelihood of planning to become teachers. Looking at the actual career outcomes of the same cohorts in the census data, I find that access to the pill had a negative impact on the share of men in teaching and positive impact on the share of women. I use information on high school grades and college selectivity in the freshmen surveys to separate students by academic ability in the analysis. I find that unionization had a negative impact on plans to become teachers among high-ability men and low-ability women. Increased access to the pill had a negative impact on the share of low-ability men who planned to teach and a positive impact on the share among low- and medium-ability women.
\end{abstract}

JEL: I21, J45, N32

Keywords: teachers, unions, career plans, gender, ability

*Steingrimsdottir: Department of Economics, Copenhagen Business School, Porcelænshaven 16A, 2000 Frederiksberg, Denmark, hs.eco@cbs.dk. I thank Jonah Rockoff, Janet Currie, Pierre-André Chiappori, and Brendan O'Flaherty for excellent advising and support, and I thank Lena Edlund and Till von Wachter for helpful comments and conversations. I also appreciate the helpful comments and suggestions made by participants in seminars at Columbia University, Copenhagen Business School, the Annual Meeting of the SOLE, the EALE conference, the Annual Meeting of PAA, the Annual Conference of RES, and the ESPE conference. All errors that remain are my own. 
In the 1960s, teaching was a prevalent occupational choice for college-educated men and women. In 1968, $15 \%$ of male and $45 \%$ of female college freshmen planned to pursue careers in teaching. In 1980, by contrast, only $3 \%$ of males and $12 \%$ of females planned to become teachers. While there was a sharp decline in the popularity of teaching among both men and women, the share of males among those who planned to teach also fell considerably, from $30.6 \%$ in 1968 to $20.0 \%$ in $1980 .^{1}$

Much of the literature on the supply of teachers focuses on women (e.g., Bacolod, 2007; Dolton and Makepeace, 1993; Flyer and Rosen, 1997; Hoxby and Leigh, 2004; Shin and Moon, 2006). Hoxby and Leigh (2004) and Corcoran et al. (2004) also focus on the quality of the female teacher supply. From a policy perspective, it is important to know how different groups of people are attracted to teaching. Some evidence suggests that students perform better when taught by people of their own gender (e.g., Dee, 2007). Boys are increasingly less likely than girls to attend college and earn bachelor's degrees, and the dearth of male teachers may be contributing to this trend.

I use college freshmen surveys from 1968 to 1980 to examine these changes. In particular, I focus on two major events from this period that may have affected the attractiveness of the teaching profession. First, in the 1970s there were significant shifts in attitudes and social norms regarding sex, marriage, and family formation, in part due to the legalization of abortion and the diffusion of the birth control pill. Increased access to abortion and the pill have been found to have substantial effects on women's family and labor market outcomes (Angrist and Evans, 1999; Levine et al., 1999; Goldin and Katz, 2002; Bailey, 2006; Guldi, 2008; Myers, 2017). Although the literature on fertility controls focuses mainly on women, theoretical arguments suggest that changes in access to fertility controls may have affected men as well through a changed market for marriage and sex (see e.g., Akerlof et al., 1996).

Second, during this period many states passed laws facilitating the unionization of the teaching sector. Unionization can affect both wages and the work environment.

\footnotetext{
${ }^{1}$ Source: my own calculations using CIRP freshmen surveys, described further in Section 3.
} 
Baugh and Stone (1982) find that teachers' unionization produced relatively small wage gains in the early 1970s but that the gains increased substantially in the late 1970s. Hoxby (1996) finds that teachers' unions increased salaries and teacher-student ratios but reduced productivity. On the other hand, Lovenheim (2009) finds that teachers' unions have no effect on pay, per-student district expenditures, or per-student revenues, but that they do increase teacher employment between 5 and 10 percent. Hoxby and Leigh (2004) focus on unions' impact on the ability composition of the teaching workforce and find that unionization caused high-aptitude women to move out of the teaching profession.

In the analysis, I exploit state-specific changes in unionization, abortion legalization, and access to oral contraceptives, to estimate the impact on the popularity of the teaching occupation among both men and women. The results show that men and women were differently affected by the changes in the 1970s. Moreover, the impact of early access to the pill and of the unionization varied with the academic ability of the students. Increased access to the pill had little overall impact on men's plans to teach, but when men are separated by academic ability (measured by their colleges' selectivity and their high school GPAs), men with low academic ability turn out to have been negatively affected. By contrast, women's teaching plans were positively affected by the availability of the pill, especially among women of medium and low academic ability.

The overall effect of unionization on the popularity of the teaching sector was negative but not significant. When the impact is separated by students' academic ability, the negative impact is strong and significant among high-ability men and low-ability women. Examining other popular career choices among college freshmen, I find that early legal access to the pill shifted men's aspirations from teaching and scientific researching, towards occupations associated with higher income, such as accounting and other business professions. Using census data, I find equivalent results when looking at actual career outcomes.

The remainder of this paper is organized as follows: Section 1 provides background on the relevant changes in the 1970s, Section 2 discusses the supply of teachers, Section 3 
describes the data and summary statistics. Section 4 presents the empirical framework, Section 5 discusses the results, and Section 6 concludes.

\section{The 1970s}

\subsection{Oral Contraceptives and Abortion Legalization}

During the 1960s and 1970s, the legalization of abortion and the availability of the birth control pill provided women with powerful tools to control and time their fertility. The use of the pill spread rapidly after its introduction in 1960, and by the end of the decade the majority of American women had used it at some point (Marks, 2001). However, many states placed considerable restrictions on access to the pill. For example, in Connecticut and Massachusetts it was prohibited to sell, distribute, or advertise any device for preventing conception, and many states forbade even the dissemination of information about contraceptives. The United States Supreme Court's decision in Griswold v. Connecticut, in 1965, made the pill more readily available, as it held that prohibitions on the use of contraceptives infringed on the fundamental rights of married people. In 1972, (in Eisenstadt v. Baird), the court extended the right to use contraception to unmarried adults as well.

In the 1960s, the women's liberation movement started lobbying for the legalization of abortion. In 1967, Colorado became the first state to decriminalize abortion in cases of rape, and incest and when the pregnancy imposed a health risk to the woman. Similar laws were passed in California, North Carolina, and Oregon, and in 1970 Hawaii became the first state to legalize abortion at the request of women. New York, Alaska, and Washington soon followed, and in Washington D.C., abortion was essentially legal from 1971 onward. On January 22, 1973, the Supreme Court decision in Roe v. Wade made abortion legal nationwide on the grounds of the constitutional right to privacy.

In addition to being limited by various state policies, access to the pill and to abortions was constrained by the legal age of majority, which was 21 in most states, because 
unmarried minors could not obtain medical care or prescriptions without parental consent. In the 1960s and 1970s, the age of majority was lowered to 18 or 19 in most states, mainly to fix legal inconsistencies, following the 26th Amendment to the Constitution. In other states, minors gained unrestricted access to oral contraceptive due to mature minor doctrines, which allowed legal infants to consent to medical care as long as they were mature enough to understand "the nature and the consequences of the treatment," or due to comprehensive family statutes that allowed physicians to treat legal minors or did not explicitly restrict them from doing so. ${ }^{2} 3$

In discussions of the effect of the pill on labor market outcomes and human capital investments, the main focus is typically on the increased control that women gained over their lives. When they were able to control and time their fertility more accurately, women's human capital investments became more profitable and their pay-offs less uncertain than before. Goldin and Katz (2002) present evidence that early access to the pill increased the share of women working in law and medicine, and Bailey (2006) finds that early access to the pill delayed fertility, increased the number of women in the paid labor force, and raised the number of hours worked by women annually. Bailey's (2012) results suggest that the introduction of the pill can explain approximately $10 \%$ of the convergence of the gender wage gap in the 1980s and $30 \%$ of that in the 1990s. Moreover, as a result of improved access to a reliable fertility control, women also gained power within the household through their increased decision rights (e.g., Chiappori and Oreffice, 2008; Oreffice, 2007).

Abortion legalization has been found to reduce teen birth rates, teen-marriage, and extra-marital births among teenage mothers (Levine et al., 1999; Angrist and Evans, 1999). Angrist and Evans (1999) furthermore find increased schooling and employment among black women who were exposed to abortion reforms as teenagers. In a recent

\footnotetext{
${ }^{2}$ The Twenty-Sixth Amendment limits the minimum voting to 18 or lower. It was ratified on July 1, 1971, in response to student activism against the Vietnam War and the fact that 18 year olds could be drafted into the military without having the right to vote.

${ }^{3}$ Goldin and Katz (2002), Bailey (2006), Guldi (2008) and Myers (2017) provide detailed discussions of the historical and legal background to access to abortion and oral contraceptives.
} 
paper, Myers (2017) looks simultaneously at the effects of early legal access (ELA) to the pill and to abortion on teenage motherhood, marriage, and shotgun marriage. Her findings suggest that it is abortion policy, rather than the pill that mainly explains the delay in family formation during this era.

Little attention has been given to the impact of increased access to fertility controls on men's labor market outcomes. ${ }^{4}$ There are several arguments for bringing men into the picture when discussing the impact of the pill, and legal abortion. First, men may have been affected through delays in marriage and fatherhood. Delayed family responsibilities might, for instance, have given them more liberty to pursue their own careers and human capital investments than before. Teaching, in particular, may have been an important outlet for college-educated men who because of family responsibilities did not have the opportunity to choose careers that required intensive human capital investment and labor market attachment. Indeed, the compatibility of teaching and family responsibilities is often mentioned in the context of women's decisions to teach, but it may also have been an important factor in the appeal of the occupation to men. The working hours, the timing and quantity of holidays, and the possibility of working partly at home (e.g., preparing and grading) allow teachers to combine parental responsibilities and work more easily than ican be done in many occupations. Furthermore, career interruptions are penalized less in teaching than in most other occupations held by college graduates. Flyer and Rosen (1997) find that whereas female college graduates take wage hits of approximately $9 \%$ for each year spent out of the labor force, teachers do not suffer any wage penalty when they temporarily leave the occupation.

Second, Akerlof et al. (1996) note how the availability of contraceptives changed social norms regarding marriage and pregnancy. Until the early 1970s, it was customary for a couple to marry in the event of pregnancy. When oral contraceptives and abortions made childbearing a physical choice on the mother's part, marriage and support became

\footnotetext{
${ }^{4}$ In an earlier paper (Steingrimsdottir, 2016), I find that both men's and women's career plans were affected by unrestricted access to the birth control pill and that men's overall aspirations shifted toward more male-dominated occupations.
} 
a social choice for the father. The effect of the pill on men could thus have been further emphasized through reduced responsibility in the case of unwanted pregnancy. Akerlof et al. (1996), for instance, relate the decline in shotgun marriages and the increase in extra-marital births to the legalization of abortion and the diffusion of the birth control pill.

Third, the shift in women's bargaining power arising from their increased control over their fertility may have created incentives for men to shift their career plans toward occupations associated with higher incomes. Women's increased bargaining power and higher human capital investments should mean higher transfers to women in the household, for example greater compensation for leaving the labor market due to childbearing. This could put pressure on men to shift their aspirations toward higher incomes.

Finally, if increased access to birth control enabled women to pursue more education and more competitive careers, wages might have become more important to men,as they felt a psychological need to uphold their role as breadwinners. Another argument, detailed by Edlund and Pande (2002), is that marriage is thought of as a contract between men and women in which men compensate women for reproductive sex and forgone market earnings. By enabling women to pursue their careers and human capital investments, the pill may have made wives more expensive, motivating men to obtain higher wages than before.

\subsection{Unionization of the Teaching Sector}

From 1955 onward, various states passed laws to facilitate or forestall teachers' unionization. After 1960, there was a legal transition in the environment for public sector unions. Between 1960 and 1990, most states extended collective bargaining rights to teachers'

unions. In some states, the right was limited to organizing for the purposes of collective bargaining, but in others teachers' unions gained the right to meet with administration representatives. Some states also passed laws allowing teachers' unions to have agency shops and union shops. A union is said to have an agency shop if it collects dues from 
all teachers in the bargaining unit, regardless of whether they are members of the union. A union shop exists when a school district cannot employ teachers who are not members of the union (Hoxby, 1996).

A union can change the characteristics of the teaching occupation along several dimensions. It may ensure a more pleasant work environment, for instance through lower student-teacher ratios, greater job security, and higher minimum salaries. But collective bargaining by unions can also result in a compressed range of pay and benefits, leaving less room to reward ability within the occupation.

A few studies address the relationship between teachers' unions, teachers' wages, and teacher supply. Baugh and Stone (1982) find that teacher unionization produced relatively small wage gains in the early 1970s but that the gains increased substantially in the late 1970s. Hoxby (1996) finds that teachers' unions increase teachers' salaries and teacher-student ratios, but reduce productivity. On the other hand, Lovenheim (2009) finds that unions have no effect on teacher pay, per-student district expenditures or perstudent revenues, but increase teacher employment by 5 to 10 percent. Arguing that unionization compressed wages in the teaching sector, Hoxby and Leigh (2004) find that unions played an important role in pushing high-aptitude women away from teaching between 1963 and 2000 .

\subsection{Vietnam}

Between 1940 and 1973, the U.S. Army relied on a sustained military draft. All 18to 25-year-old men were judged by local boards, with the most common classifications being I-A (ready for duty), II-S (student deferment), III-A (hardship deferment), and IV-F (unfit for service). Men were technically draft-eligible until their 26th birthday, but the average age was between 19 and 20; very few men were drafted after their 23rd birthday (Kuziemko, 2010).

It appears to have initially been quite easy to get deferments and exemptions. For example, in 1964 one-third of 18-year-old men were deemed unfit for service. Moreover, 
being drafted seldom led to combat duty. As the Vietnam War surged, however, quotas increased and deferments grew harder to obtain. After 1967, anyone enrolled as a fulltime undergraduate student at a college or university was granted II-S status. Card and Lemieux (2001) find that draft avoidance raised college attendance rates by 4 to 6 percentage points in the late 1960s, introducing a potential selection problem for studying college students in this period. There is also anecdotal evidence that one could get an exemption by teaching high school in underprivileged areas.

The military draft may also have affected people's career plans through its impact on fertility and family formation. Bitler and Schmidt (2012) point out that the draft led to the absence of men from local marriage markets, which may have affacted matching and fertility behavior. They find that birth rates among women aged 15-30 decreased when more men aged 19-20 were drafted.

Although there was some state-specific variation in draft avoidance, the risk known ex ante was year specific (Malamud and Wozniak, 2012). In the analysis, this should therefore be captured by year fixed effects. For further robustness, the analysis is repeated using only survey years after the draft ended.

\subsection{Title IX}

Title IX of the Education Amendments was enacted in 1972. It states "No person in the United States shall on the basis of sex, be excluded from participation in, be denied the benefits of, or be subjected to discrimination under any education program or activity receiving Federal financial assistance" (United States Code Section 20). ${ }^{5}$ Although some activities were exempt from Title IX, such as fraternities, sororities, and sex-specific youth clubs such as Girl and Boy Scouts, Title IX did apply to athletics; in fact, its largest effect may have been on high-school and college sport. In the first six years after Title IX was passed, the number of women participating in high school sports rose from 1 in 27 to 1 in 4 while male participation remained the same at about 1 in 2 (see Stevenson, 2010).

\footnotetext{
${ }^{5}$ See, e.g., http://law.cornell.edu/uscode/20/1681.html
} 
Stevenson (2010) finds that participation in athletics increased college attendance and labor force participation among women. ${ }^{6}$

Many people have contended that Title IX led to the dismantling of some popular men's sport programs. Consequently, Title IX may have reduced high school teachers' opportunities to coach boys in athletics, and in that way reduced the attractiveness of teaching for males. The empirical analysis includes year fixed effects, and state specific time trends, which should capture the effect of Title IX on men's decision to become teachers.

\subsection{The Demand for Teachers}

In the United States, K-12 enrollment increased rapidly in the 1950s and 1960s, reflecting the "baby boom," the large birth cohorts following World War II. Enrollment peaked in 1971, and then there was a rapid decline until the mid 1980s. If college students anticipated a reduced demand for teachers in the future because of smaller birth cohorts, it may have affected their career plans. However, the pupil-teacher ratio declined during the same period, and the number of teachers in elementary and secondary schools remained fairly stable. ${ }^{7}$

\section{The Supply of Teachers}

The share of college freshmen who planned on careers in teaching dropped substantially in the 1970s. Figure 1 shows the share of male freshmen who planned to teach by their academic ability. The figure indicates that teaching was a popular career choice in the beginning of the period, especially among men of medium and low academic ability. Then in the early 1970s there was a sharp decline, which then stabilised toward the end of the

\footnotetext{
${ }^{6}$ Stevenson (2007) points out that participation in high school sports is more common among students from privileged backgrounds, and consequently that Title IX benefitted women from households at the top of the income distribution disproportionately.

${ }^{7}$ In 1970, there were 2,292,000 teachers in elementary and secondary schools. In 1985, there were 2,549,000. See, e.g., https://nces.ed.gov/programs/digest/d17/figures/fig 7. asp? referrer = figuresandhttps://nces.ed.gov/programs/digest/d16/tables/dt16 ${ }_{1} 05.40 . a s p$
} 
decade. A similar pattern can be observed among women in Figure 2, although teaching was more popular among high- and medium- ability women than among those with lower academic ability.

When studying the teaching sector, it is important to bear in mind some of its specific characteristics. First, the occupation is heavily dominated by women and has been seen as an attractive choice for women who want to combine work and family responsibilities. Second, the teaching sector is controlled by the government to a large extent, and the demand for teachers and wages is for the most part set by government authorities. ${ }^{8}$ The pay schemes and promotional ladder are fairly rigid, and there is little room for financial rewards for good performance. Third, teaching is a heavily unionized sector. Unions affect the wage structure of the profession but also play important role in shaping the job itself and its non-pecuniary characteristics, such as security, flexibility, work conditions, and prestige, which are likely to contribute significantly to the job's attractiveness and are thus an important factor in he supply of teachers.

While some researchers find that higher incomes draw more people into the occupation (e.g., Manski, 1987; Dolton, 1990), others find little or no effect of relative teacher earnings (e.g., Hanushek and Pace, 1995). The literature on teacher supply focuses largely on women (e.g., Dolton and Makepeace, 1993; Flyer and Rosen, 1997; Corcoran et al., 2004) or uses pooled results for men and women, however. After separating the effects of pay increases, Chevalier et al. (2007) find that although they have a significant effect on both men's and women's decisions to teach, men are more likely to react to a wage hike than women. Dolton and Mavromaras's (1994) results suggest that gender differences in characteristics and labor market barriers explain the gap in their propensity to become teachers. If men made decisions like women, more of them would enter teaching, whereas women who acted like men would move from teaching to the private sector. Dolton (2006) reported that : ...examination of the pattern of life cycle earnings for men in the USA

\footnotetext{
${ }^{8}$ Around $10 \%$ of students in elementary and secondary schools in the United States are enrolled in private schools. See e.g., https://nces.ed.gov/programs/digest/d16/tables/dt16 ${ }_{2} 05.10$.asp? current $=$ yes
} 
and the UK in teaching and nonteaching alternative shows that if earnings were the only criteria used to decide a career then no men would become teachers in these countries. It is therefore important to consider other possible factors in the decision to become a teacher.

\section{Data}

The primary source of data for the analysis is the Cooperative Institutional Research Program's (CIRP) Freshman Surveys, which have been conducted annually by the UCLA Higher Education Research Institute since 1966. Each year, the survey is administered to all incoming freshmen at more than 700 colleges and universities. Nearly $90 \%$ of the institutions are repeat participants, and to ensure consistency and minimize response bias, each cohort is stratified and weighted to be a nationally representative sample of first-time, full-time students entering institutions of higher education in each year. ${ }^{9}$ The analysis includes surveys from 1968, 1969, and 1972 through 1980. The 1966 and 1970 surveys were not accessible. The 1967 survey is excluded because it lacks a measure for college selectivity, and the 1971 survey is omitted because information on the state of the institution is missing. The analysis is restricted to students who were between 17 and 19 years old at the end of their first year of college. ${ }^{10}$ Notably, these surveys are quite large; they contain around 270,000 students per survey year on average, and pooled across years, almost 3.5 million students in total.

To compare the changes in career plans to actual changes in labor market outcomes, I use the 5\% Public Use Microdata Samples of the 1980 and 1990 censuses. In the census analysis, I include the 1942-1958 birth cohorts. The census data does not include

\footnotetext{
${ }^{9}$ The defined population consists of all "eligible" institutions of higher education listed by the U.S. Office of Education in its annual Education Directory. An institution is considered "eligible" if it is functioning at the time of the survey and has the equivalent of a first-time entering freshman class of at least 30 students. The data are stratified into 37 cells based on the institutions's characteristics and weighted by these cells to account for disproportionate sampling. Moreover, the weights adjust for less than $100 \%$ participation by students at individual institutions. This is done separately by sex (see National Norms for Entering College Freshmen - Fall 1970 (1970))

${ }^{10} 89 \%$ of the students in the sample are between 17 and 19 years old.
} 
information on the state of the college attended, so it is assumed that people attended college in their reported states of residence. The census' person weights are used to obtain nationally representative statistics and results.

\subsection{Career Plans}

Table 1 shows the occupational characteristics for teaching, and the top ten career plans among male college freshmen in 1968. It shows the average income and the share of males for each occupation, drawn from the 1970 census. It also shows the Siegel prestige score, which is based on series of surveys conducted through the National Opinion Center in which respondents were asked to evaluate either the"general standing" or the "social standing" of occupations. These surveys were conducted from 1963 to 1965 and are therefore likely to capture people's sentiments toward various occupations right before the period of study.

Teaching stands out among the occupations for particularly low income, prestige, and share of males. There is little change in the popularity of the occupations with the highest income and prestige scores, such as doctors and lawyers. On the other hand, occupations such as engineering, accounting, and computer programming are increasingly favored by men as planned careers over the period.

Table 2 displays the most popular career choices among female freshmen. In 1968, teaching was by far the most popular, followed by nursing. Although teaching was still popular in 1980, business executive had become the most popular career plan among women. Other occupations associated with higher income and higher male ratios, such as accounting and computer programming, had also become more popular.

\subsection{Who Plans to Teach?}

Table 3 compares the characteristics of students who planned to teach in 1968, with those who plan on other careers. Men who planned to teach were disproportionally drawn from 
the lower end of the academic ability distribution, while female teacher aspirants were more likely to come from the medium ability group. This pattern reflects the gender differences in occupational choices at the time. Table 1 shows that among men's most popular career choices, teaching stands out in terms of earnings. The average income for teaching was considerably lower than that in engineering, business, law, and medicine. For women, by contrast, earnings in the teaching occupation were comparable to those in many other popular occupations, including clerical work, nursing and social work. ${ }^{11}$ Both men and women who planned to teach were less likely to come from high-income households, and less likely to have college-educated parents than other freshmen. Table 4 displaying the same statistics from the 1980 Survey, shows similar patterns, although the ability distribution for males is less skewed toward those with lower academic ability than it was in 1968.

\section{Empirical Framework}

I estimate a fixed effect probit model of the following form:

$$
\begin{aligned}
& \operatorname{Pr}\left(\text { Teach }_{i s c}\right)=F\left(\alpha_{s}+\alpha_{c}+\beta_{\text {pill }} \text { Pill }_{\text {sc }}+\beta_{\text {abortion }} \text { Abortion }_{\text {sc }}\right. \\
& \left.+\beta_{\text {union }} \text { Union }_{\text {sc }}+\gamma \log \left(W_{\text {teach }} / W_{\text {other }}\right)+X_{\text {isc }}\right) \text {, }
\end{aligned}
$$

where Teach $_{i s c}$ is a binary variable equal to 1 if the respondent plans on a career in teaching. Pill sc takes value 1 if the student's state and cohort are such that the student

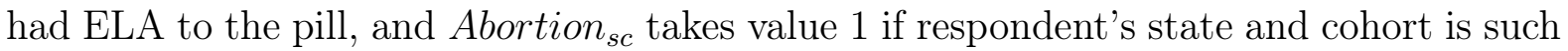
that she had ELA to abortions.

In keeping with the previous literature, I use state and cohort variation to identify the impact of early exposure to the pill and to abortions. Several research teams have

\footnotetext{
${ }^{11}$ Women in the high-ability group were more likely to choose occupations like physician and scientist that almost no women in the low group chose. Instead women in the low group were more likely to choose clerical work and nursing than women in the medium and high groups.
} 
sought to code the timing of ELA to the pill and abortion by state (Goldin and Katz, 2002; Bailey, 2006; Guldi, 2008; Hock, 2007; Bailey et al., 2011; Myers, 2017). There are considerable disparities between these codings, however. The coding used by Myers (2017) differs from that of Goldin and Katz (2002) for 27 states, from that of Bailey (2006) for 20, from that of Guldi (2008) for 16, from that of Bailey et al. (2011) for 14, and from that of Hock (2007) for 8 states (see Myers, 2017). These discrepancies are due in part to some errors in the coding (e.g. Bailey et al. (2011) corrected several errors in the coding of Bailey (2006) and Guldi (2008)), and in part to differences in interpretation of the laws. For instance, Bailey et al. (2011) assumes that women did not gain access to the pill until the age of majority was lowered for both men and women, while Myers (2017) assumes that women gain access when the age of majority for women was lowered to eighteen; this explains the main differences in their codings. In this study I follow the most recent coding, that of Myers (2017), for state and cohort variation in ELA to the pill (see documentation in Tables A.1 and A.2). Furthermore, I check the robustness of the main results to those using the coding of Bailey et al. (2011) (see Table A.5).

Union $_{s c}$ is an indicator variable that takes value 1 if the state has passed a law facilitating teachers' unionization. Following Hoxby (1996) and Hoxby and Leigh (2004), I include laws that extended the right to meet or engage in collective bargaining and laws that allow teachers' unions to have agency shops and union shops (see Table A.3).

Figure A.1 shows the cumulative number of states to have adopted each of these laws (pill, abortion, and teachers' unionization), and Figure A.2 shows the year in which each law was adopted in each state. These figures show that there is little variation in ELA to abortion, so much of its impact may be absorbed by the year fixed effects, but there is also little overlap between the laws: only few states changed two or more of these laws simultaneously.

I also control for relative wages. I use the Current Population Survey (CPS) to calculate teachers' wages relative to other college educated workers. I calculate these separately for men and women, and I restrict the sample to workers aged 25 to 55 , to 
eliminate problems associated with joint school and work activities, and with retirement. Finally, to account for variation in expected demand for teachers, I control for the size of the birth cohort in the year before the survey year (college freshmen would have information on cohort size, and this birth cohort would be starting school around the same time as they would start teaching careers.)

$X_{i s c}$ includes controls for race, being Catholic, and parents' education. The specification includes state and cohort fixed effects. To address the concern that the parameters of interest capture social trends, or other gradually evolving, unobserved state characteristics, I add state specific time trends. Standard errors are robust and are clustered by state, to reflect the nature of the variation in the explanatory variables of interest.

\subsection{Academic Ability}

Evidence suggests that ELA to abortion and the pill varied among populations. In the first years after oral contraceptives became available, more educated women were more likely to use it than less educated women (Marks, 2001). Andalón et al. (2014) also find an education gradient in women's probability of using some kind of contraception at their sexual debut, and Cooksey (1990) finds that teenagers' deciding to terminate pregnancies is positively correlated with their mother's education. If women at the lower end of the ability distribution are less likely to use the pill, they may be negatively affected by ELA because of the increased likelihood that they will have to face the consequences of premarital sex alone. By contrast, women at the top of the distribution are more likely to adopt the pill and be positively affected by ELA (see, e.g., Akerlof et al., 1996). If unionization increases the non-pecuniary benefits of teaching and perhaps the average pay at the same time as wages become more compressed (see e.g., Hoxby and Leigh, 2004), this is likely to affect different ability groups in different ways. To address potential heterogeneity in the impact of unionization and ELA to the pill and abortion, I separate students by academic ability in the analysis.

There are two measures of academic achievement available in the CIRP surveys: high 
school grade point average and college selectivity. The latter is a categorical measure based on the median SAT composite scores of the entering class, and it takes one of six values: very high, high, medium, low, and very low, or no selectivity. ${ }^{12}$ High school grades are self-reported and take values from 1 (D or lower) to $8(\mathrm{~A} / \mathrm{A}+)$. Both of these measures are imperfect, and each gives a somewhat different picture of students' abilities: the correlation between them is only .234 . However, both measures are likely to provide some indication of students' academic ability.

I use these two variables to divide students into high, medium, and low ability groups. To count as high ability, a student from a highly selective institution musth have a GPA of $\mathrm{B}$ or higher, a student from a medium selectivity institution must have a a $\mathrm{B}+$ or higher, and a student from an institution with low or no selectivity must have an A- or higher. To be in the medium ability group, a student from a highly selective institution needs a GPA between C and B-, a student from a medium selectivity institution needs one from $\mathrm{C}+$ to $\mathrm{B}$, and a student from an institution with low or no selectivity needs a $\mathrm{B}$ ora $\mathrm{B}+$. Students with lower GPAs are placed in the low-ability category. Using the sample weights discussed above, this categorization gives a distribution where $26.8 \%$ are in the high ability group, $39.2 \%$ are in the medium ability group, and $34.0 \%$ are in the low ability group. In the analysis, I estimate the impact separately for each ability group. In the Appendix, I show further results when students are categorized by their college selectivity and high school GPA (Tables A.7 and A.8).

\section{Results}

\subsection{Impact on Teaching Aspirations}

Table 5 shows the estimated impact on the probability that male freshmen plan to become teachers. Column (i) shows the effect for all men, while columns (ii)-(iv) separate men by

\footnotetext{
${ }^{12}$ The approximate range of mean SAT scores is $<999$ for students entering low-selectivity institutions, 1,000-1,149 for medium, 1,150-1,249 for high, and > 1,250 or higher for very highly selective institutions.
} 
their ability. The reported coefficients are the marginal effects from a probit regression, estimated at the means of the independent variables. The overall estimates are small and not significant, but when men are separated by ability we see that the teaching plans of high-ability men are negatively affected by unionization but positively affected by ELA to abortion. Among low-ability men, ELA to the pill has a significantly negative effect, decreasing the probability that men plan to teach by 1.2 percentage points. Higher relative wages attract low-ability men to teaching, and larger birth cohorts (proxying increased future demand for teachers) attract both low- and high-ability men to teaching.

Table 6 shows the estimated effects for women. When we look at the overall effect in column (i) we see that ELA to pill has a positive effect on the probability that women plan to become teachers. Women are also more likely to plan to teach when birth cohorts are larger. Surprisingly, however, women appear to be less likely to plan to teach when the relative wages of teachers are higher. When women are separated by ability, we see that the positive effect of the pill are concentrated in the medium- and low-ability groups. The marginal effects indicate that the pill increases the probability of choosing teaching by 1.6 percentage points, and by 1.9 percentage points for women in the low-ability group. Unionization has a significant negative impact on women in the low-ability group, reducing the probability of these women's choosing teaching by 1.7 percentage points.

\subsection{Impact of the Pill on Other Career Plans}

Early legal access to the pill reduces probability that low-ability men will choose to become teachers. To provide further details on these changes, I estimate the effect of the pill on the probability of men choosing other popular career options (listed in Table 1). In Table 7 these occupations are ordered by average income in 1970, with physicians having the highest income, and computer programmers the lowest among them. The results indicate that men shifted their aspirations toward better paid occupations such as accounting and business ownership (medium and low ability males), or from scientific 
research to business executive work (high-ability men). Table 8 estimates the impact on women's career plans. Women also appear to have become more likely to choose business executive positions (high-ability women) or accounting (medium- and low-ability) for their career, while women in the medium-ability group became less likely to choose lab technician and therapist as their planned careers.

In Tables A.13 and A.14 I look at the impact of the pill, unionization, abortion legalization, relative wages of teachers, and cohort size, on the main career outcomes for men and women. I group similar occupations together, for instance law and medicine (colums (i)-(iii)), or accounting and business executive (referred to as "Business" in Columns (iv)(vi)). Finally, I look at engineering for men (Columns (vii)-(ix) of Table A.13), and nursing and clerical work for women ((columns (vii)-(ix) of Table A.14).

\subsection{Impact on Actual Career Outcomes in the Census Data}

To further investigate whether changed career plans actually manifested in changed occupation, I look at actual career outcomes in the census data. The results in Table 9 focus on teaching. The estimates support the previous findings, that ELA to the pill had a negative effect on men's decisions to become teachers but a positive effect on women's. The estimated coefficients are significant but smaller than the estimated effects on career plans. Among women, ELA to abortion has a significant negative relation to probability of being a teacher.

In Table 10 I look at the impact of ELA to the pill on other career choices. The findings for men indicate that males did indeed shift their occupational choices toward better paid occupations, such as engineers, and business executives. Women appear to have shifted from nursing, toward teaching, that is, although the impact on their likelihood of teaching was opposite of that on men, they also appear to have moved toward (slightly) better paid occupations. 


\subsection{Robustness Checks}

I perform several robustness checks to test the validity of the findings. First, Table A.4 shows the logit estimates which, are almost identical to the estimates in Tables 5 and 6 . Second, I use and alternative coding for ELA to the pill, namely the coding suggested by Bailey (2012). These results are shown in Table A.5. Although the estimated coefficients have the same signs as before, they differ in size and preciseness. The estimated impact of the pill on low-ability men and medium-ability women is not significant. By contrast, the estimated effects of both the pill and unionization on low-ability women are comparable with previous findings.

In Section 1.3, I discuss the potential impact of the Vietnam draft on men's decisions to attend college and to teach. I repeat the main analysis using only survey years from after the draft ended. The results (see Table A.6) include similar estimates to those in Tables 5 and 6, although the coefficient for low-ability women is not significant in this specification.

In Tables A.7 and Tables A.8 I use alternative measures of academic ability for men and women. Columns (i)-(iii) show the results when students are sorted by the college selectivity, and columns (iv)-(vi) when they are sorted by high-school GPA. As discussed in Section 4.1, these measures give somewhat different pictures of students' academic ability, and it is therefore not surprising to find some differences in the estimated coefficients. When males are divided by college selectivity, the pill is found to negatively affect those in both high- and low-selective colleges. When women are divided by high school grades, the pill is found to positively affect those in all ability groups, although the largest impact is on the low-ability group. When they are divided by college selectivity, the pill is found to have a positive impact on those in colleges with medium and low selectivity. The negative impact of unionization is concentrated among women with low high school grades.

Tables A.9 and A.10 show that the main findings of this paper are robust to alternative measures of relative wages. Finally, Tables A.11 and A.12 show that estimating the main 
independent variables separately produces similar results to those seen in column (i) of Tables 5 and 6 .

\section{Conclusion}

In this paper, I show that the popularity of the teaching occupation decreased drastically among both male and female college students in the 1970s. In recent decades, dispropotionally many men have left the profession making teaching an increasingly female dominated occupation. There have also been concerns that high-aptitude college graduates have become less likely to enter the teaching sector. As evidence emerges on both the importance of high quality teaching, and students' greater responsiveness to teachers of their own race and gender, it should be the aim of policy makers to attract high-ability people from all demographic groups into teaching. As male high school students are being outperformed in the classroom by their female peers, and the gender gap that favors women in college enrollment and completion rates is widening, and it may become increasingly important to attract able men into teaching.

In this study, I look at whether certain major changes that took place in the 1970s, such as the availability of birth control and the unionization of the teaching sector can explain why teaching became a less attractive career for college students. Unionization has some explanatory power, in particular among high-ability men, and low-ability women. The birth control pill also contributed to the disappearance of men from the teaching sector, as they shifted their career plans toward occupations associated with higher wages. By contrast, the pill had a positive impact on the share of females choosing teaching as their planned career.

It has been emphasized that teaching is an attractive alternative for women who want to combine work with family responsibilities, as it provides more flexibility and security than other careers. The findings here suggest that this may also have been an important factor in men's decisions to teach. When family responsibilities became less restrictive 
at the same time as the pressure to earn higher income may have gone up, the value of these features is likely to have diminished. With other policies now making it easier for people to combine work and family, (e.g., increased parental leave and daycare provision) teaching is becoming even less competitive. 


\section{References}

Akerlof, George A., Janet L. Yellen, and Michael L. Katz, "An Analysis of Outof-Wedlock Childbearing in the United States," The Quarterly Journal of Economics, 1996, $111(2), 277-317$.

Andalón, Mabel, Jenny Williams, and Michael Grossman, "Empowering Women: The Effect of Schooling on Young Women's Knowledge and Use of Contraception," Technical Report, NBER, Cambridge, MA 2014.

Angrist, Joshua D. and William N. Evans, "Schooling and Labor Market Consequences of the 1970 State Abortion Reforms," Research in Labor Economics, 1999, 18, $75-113$.

Bacolod, Marigee P., "Do Alternative Opportunities Matter? The Role of Female Labor Markets in the Decline of Teacher Quality," The Review of Economics and Statistics, 2007, 89 (4), 737-751.

Bailey, Martha J., "More Power to the Pill : The Impact of Contraceptive Freedom on Women's Life Cycle Labor Supply," The Quarterly Journal of Economics, 2006, 121 (1), 289-320.

Bailey, Martha J, "Reexamining the impact of the US family planning programs: Evidence from the War on Poverty, 1964-1973," American Economic Journal: Applied Economics, 2012, 4 (2), 62-97.

_, Melanie Guldi, Allison Davido, and Erin Buzuvis, "Early Legal Access: Laws and Policies Governing Contraceptive Access, 1960-1980," Technical Report 2011.

Baugh, William H. and Joe A. Stone, "Teachers, Unions, and Wages in the 1970s: Unionism Now Pays," Industrial and Labor Relations Review, 1982, 35 (3), 368-376.

Bitler, By Marianne P and Lucie Schmidt, "Birth Rates and the Vietnam Draft," American Economic Review: Papers and Proceedings, 2012, 102 (3), 566-569. 
Card, David and Thomas Lemieux, "Going to College to Avoid the Draft: The Unintended Legacy of the Vietnam War," American Economic Review, 2001, 91 (2), $97-102$.

Chevalier, Arnaud, Peter Dolton, and Steven McIntosh, "Recruiting and Retaining Teachers in the UK: An Analysis of Graduate Occupation Choice from the 1960s to the 1990s," Economica, feb 2007, 74, 69-96.

Chiappori, Pierre-Andre and Sonia Oreffice, "Birth Control and Female Empowerment: An Equilibrium Analysis," Journal of Political Economy, 2008, 116 (1), 113-140.

Cooksey, E C, "Factors in the Resolution of Adolescent Premarital Pregnancies.," Demography, 1990, 27 (2), 207-218.

Corcoran, Sean P., William N. Evans, and Robert M. Schwab, "Changing LaborMarket Opportunities for Women and the Quality of Teachers, 1957-2000," American Economic Review, 2004, 94 (2), 230-235.

Dee, Thomas S., "Teachers and the Gender Gaps in Student Achievement," The Journal of Human Resources, 2007, 42 (3), 528-554.

Dolton, P. J. and G. H. Makepeace, "Female Labour Force Participation and the Choice of Occupation - The Supply of Teachers," European Economic Review, 1993, 37, 1393-1411.

Dolton, Peter J., "The Economics of UK Teacher Supply: The Graduate's Decision," The Economic Journal, 1990, 100 (400), 91-104.

_ , "Teacher Supply," in Eric A. Hanushek and Finis Welch, eds., Handbook of the Economics of Education, Vol. 2, Elsevier B.V., 2006, pp. 1079-1161.

_ and Kostas G. Mavromaras, "Intergenerational Occupational Choice Comparisons: The Case of Teachers in the UK," The Economic Journal, 1994, 104 (425), 841-863. 
Edlund, Lena and Rohini Pande, "Why Have Women Become Left-Wing ? The Political Gender Gap and the Decline in Marriage," The Quarterly Journal of Economics, 2002, 117 (August), 917-961.

Flyer, Fredrick and Sherwin Rosen, "The New Economics of Teachers and Education," Journal of Labor Economics, 1997, 15 (1), 104-139.

Goldin, Claudia and Lawrence F Katz, "The Power of the Pill : Oral Contraceptives and Women's Career and Marriage Decisions," Journal of Political Economy, 2002, 110 (4), 730-770.

Guldi, Melanie, "Fertility Effects of Abortion and Birth Control Pill Access for Minors," Demography, 2008, $45(4), 817-827$.

Hanushek, Eric and Richard R. Pace, "Who Chooses to Teach (and Why)?," Economics of Education Review, 1995, 14 (2), 101-117.

Hock, Heinrich, "The Pill and the College Attainment of American Women and Men," Technical Report, Florida State University 2007.

Hoxby, Caroline M., "How Teachers' Unions Affect Education Production," The Quarterly Journal of Economics, 1996, 111 (3), 671-718.

_ and Andrew Leigh, "Pulled Away or Pushed Out? Explaining the Decline of Teacher Aptitude in the United States," American Economic Review, 2004, 94 (2), 236-240.

Kuziemko, Ilyana, "Did the Vietnam Draft Increase Human Capital Dispersion? DraftAvoidance Behavior by Race and Class," Princeton mimeo, 2010, (January).

Levine, Phillip B., Douglas Staiger, Thomas J. Kane, and David J. Zimmerman, "Roe v Wade and American fertility," American Journal of Public Health, 1999, 89 (2), 199-203. 
Lovenheim, Michael F., "The Effect of Teachers' Unions on Education Production: Evidence from Union Election Certifications in Three Midwestern States," Journal of Labor Economics, 2009, 27 (4), 525-587.

Malamud, Ofer and Abigail Wozniak, "The Impact of College on Migration: Evidence from the Vietnam Generation," Journal of Human Resources, 2012, 47 (4), 913-950.

Manski, Charles F., "Academic Ability, Earnings , and the Decision to Become a Teacher: Evidence from the National Longitudinal Study of the High School Class of 1972," in David A. Wise, ed., Public Sector Payrolls, Chicago: University of Chicago Press, 1987, pp. 291-316.

Marks, Lara V., Sexual Chemistry: A History of the Contraceptive Pill, Yale University Press, 2001.

Myers, Caitlin, "The Power of Abortion Policy: Re-Examining the Effects of Young Women's Access to Reproductive Control," Journal of Political Economy, 2017, 125 (6), 694293 .

National Norms for Entering College Freshmen - Fall 1970

National Norms for Entering College Freshmen - Fall 1970, Technical Report 5, American Council on Education 1970.

Oreffice, Sonia, "Did the Legalization of Abortion Increase Women's Household Bargaining Power? Evidence from Labor Supply," Review of Economics of the Household, 2007, 5 (2), 181-20\%.

Shin, Jaeun and Sangho Moon, "Fertility, Relative Wages, and Labor Market Decisions: A Case of Female Teachers," Economics of Education Review, 2006, 25 (6), $591-604$. 
Steingrimsdottir, Herdis, "Reproductive rights and the career plans of U.S. college freshmen," Labour Economics, 2016, 43 (7), 29-41.

Stevenson, Betsey, "Title IX and the Evolution of High School Sports," Contemporary Economic Policy, 2007, 25 (4), 486-505.

_ , "Beyond the Classroom: Using Title IX to Measure the Return to High School Sports," Review of Economics and Statistics, 2010, 92 (2), 284-301. 


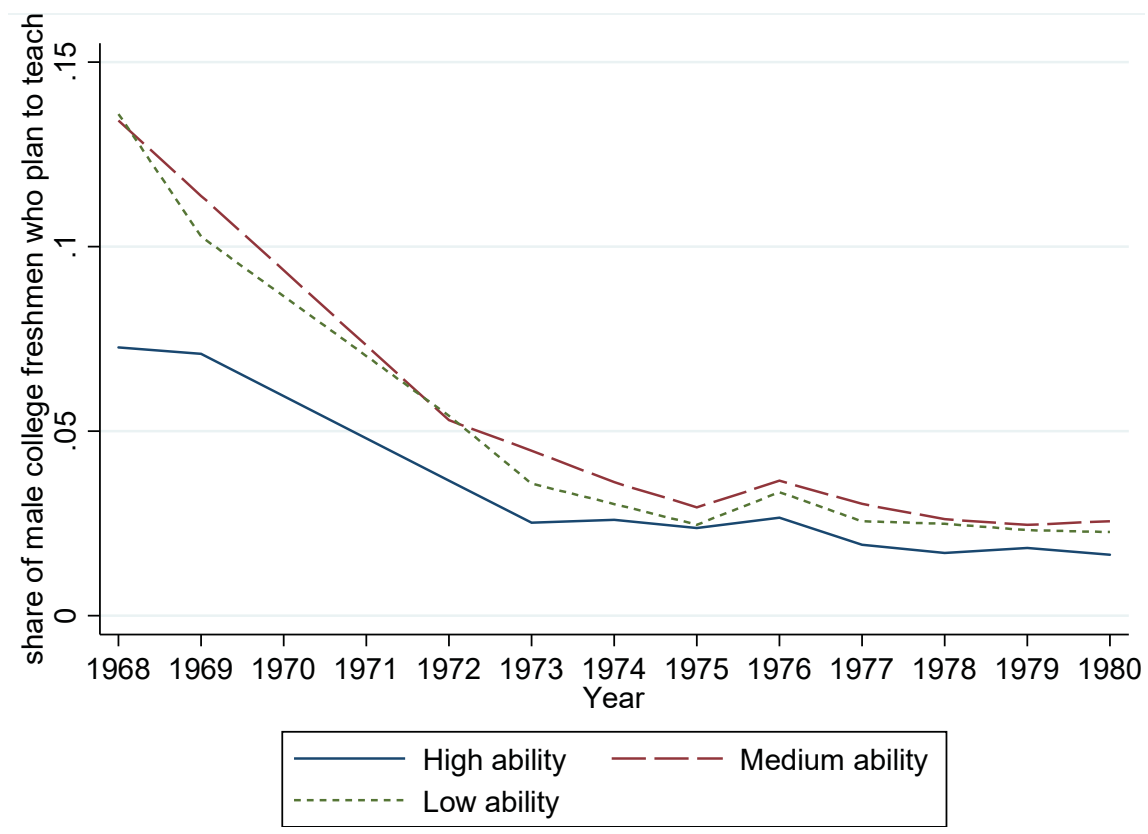

Figure 1: Male teacher aspirants among college freshmen, by academic ability. (Source: CIRP Surveys)

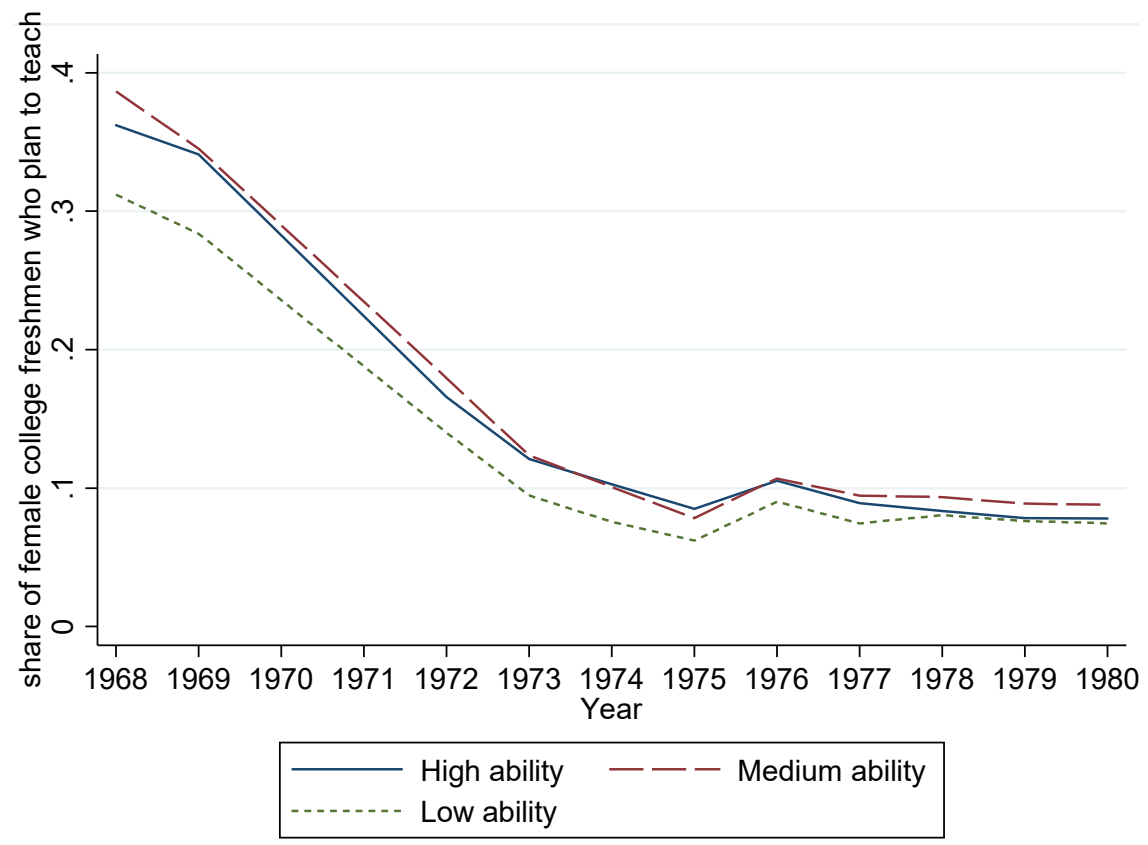

Figure 2: Female teacher aspirants among college freshmen, by academic ability. (Source: CIRP Surveys) 
Table 1: Men's Career Plans and Occupational Characteristics

\begin{tabular}{|c|c|c|c|c|c|c|c|}
\hline \multirow[b]{2}{*}{ Planned Career } & \multicolumn{2}{|c|}{ Career Plans 1968} & \multicolumn{2}{|c|}{ Career Plans 1980} & \multicolumn{3}{|c|}{ Occupational Characteristics } \\
\hline & Rank & $\%$ & Rank & $\%$ & Average income & $\%$ males & Prestige \\
\hline Engineer & 1 & 18.3 & 1 & 22.0 & $15,174.0$ & 98.6 & 64.4 \\
\hline Secondary Teacher & 2 & 13.9 & 10 & 2.4 & $8,149.4$ & 51.5 & 59.6 \\
\hline Business Executive & 3 & 12.7 & 2 & 14.3 & $16,646,7$ & 87.2 & 50.3 \\
\hline Lawyer & 4 & 6.9 & 5 & 5.4 & $21,771.4$ & 95.9 & 75.7 \\
\hline Physician & 5 & 4.8 & 7 & 5.1 & $26,870.6$ & 92.0 & 81.5 \\
\hline Scientific Researcher & 6 & 4.7 & 9 & 3.0 & $11,437.6$ & 73.1 & 78.3 \\
\hline Accountant & 7 & 4.5 & 4 & 7.0 & $12,982.4$ & 92.0 & 56.7 \\
\hline Architect & 8 & 2.9 & 8 & 3.0 & $16,862.3$ & 96.9 & 70.5 \\
\hline Computer Programmer & 9 & 2.9 & 3 & 7.3 & $9,555.2$ & 75.5 & - \\
\hline Business Owner & 10 & 2.5 & 6 & 5.3 & $13,216.5$ & 86.0 & 37.6 \\
\hline Elementary Teacher & 17 & 1.5 & 23 & 0.7 & $6,933.4$ & 16.6 & 59.6 \\
\hline
\end{tabular}

Notes: Average income and share of males are calculated from the 1970 census, using college graduates who are currently employed. The prestige scores are assigned to the 1950 occupational codes in the census, in which there is only one group for non-college teaching. The score therefore applies to both elementary and secondary school teaching. There is no prestige score for computer programmers available in the census data. 
Table 2: Women's Career Plans and Occupational Characteristics

\begin{tabular}{|c|c|c|c|c|c|c|c|}
\hline \multirow[b]{2}{*}{ Planned Career } & \multicolumn{2}{|c|}{ Career Plans 1968} & \multicolumn{2}{|c|}{ Career Plans 1980} & \multicolumn{3}{|c|}{ Occupational Characteristics } \\
\hline & Rank & $\%$ & Rank & $\%$ & Average income & $\%$ males & Prestige \\
\hline Elementary Teacher & 1 & 23.6 & 3 & 8.5 & $6,933.4$ & 16.6 & 59.6 \\
\hline Secondary Teacher & 2 & 21.5 & 12 & 3.0 & $8,149.4$ & 51.5 & 59.6 \\
\hline Nurse & 3 & 7.8 & 2 & 11.6 & $6,642.1$ & 3.8 & 61.5 \\
\hline Clerical & 4 & 6.7 & 6 & 4.7 & $5,920.2$ & 10.2 & 44.5 \\
\hline Social Worker & 5 & 6.1 & 8 & 4.2 & $8,115.3$ & 37.1 & 52.4 \\
\hline Artist & 6 & 3.1 & 13 & 2.9 & $9,934.0$ & 64.8 & 56.2 \\
\hline Therapist & 7 & 2.6 & 7 & 4.4 & $8,250.1$ & 31.9 & 36.7 \\
\hline Computer Programmer & 8 & 2.1 & 5 & 6.2 & $9,555.2$ & 75.5 & - \\
\hline Homemaker & 9 & 2.1 & 34 & 0.3 & - & - & - \\
\hline Lab Technician & 10 & 2.0 & 14 & 2.7 & $9,829.6$ & 71.5 & 50.2 \\
\hline Business Executive & 14 & 1.6 & 1 & 12.2 & $16,646,7$ & 87.2 & 50.3 \\
\hline Accountant & 15 & 1.4 & 4 & 8.0 & $12,982.4$ & 92.0 & 56.7 \\
\hline Physician & 16 & 1.3 & 10 & 3.6 & $26,870.6$ & 92.0 & 81.5 \\
\hline Lawyer & 24 & 0.8 & 9 & 4.1 & $21,771.4$ & 95.9 & 75.7 \\
\hline
\end{tabular}

Notes: Average income and share of males are calculated from the 1970 census, using college graduates who are currently employed. The prestige scores are assigned to the 1950 occupational codes in the census, in which there is only one group for non-college teaching. The score therefore applies to both elementary and secondary school teaching. There is no prestige score for computer programmers available in the census data. 
Table 3: Summary Statistics: Freshmen Who Plan to Teach vs. Freshmen who Plan on Other Careers - 1968 Survey

\begin{tabular}{|c|c|c|c|c|c|c|}
\hline & \multicolumn{3}{|c|}{ Men } & \multicolumn{3}{|c|}{ Women } \\
\hline & $\begin{array}{l}\text { Teach } \\
\text { (i) }\end{array}$ & $\begin{array}{l}\text { Other career plans } \\
\text { (ii) }\end{array}$ & $\begin{array}{l}\text { Difference } \\
\quad \text { (iii) }\end{array}$ & $\begin{array}{l}\text { Teach } \\
\text { (iv) }\end{array}$ & $\begin{array}{l}\text { Other career plans } \\
\qquad(\mathrm{v})\end{array}$ & $\begin{array}{l}\text { Difference } \\
\quad(\mathrm{vi})\end{array}$ \\
\hline \multicolumn{7}{|l|}{ Academic Ability } \\
\hline High & .271 & .419 & $-.148 * * *$ & .480 & .509 & $-.029 * * *$ \\
\hline Medium & .417 & .350 & $.067^{* * *}$ & .377 & .331 & $.046^{* * *}$ \\
\hline Low & .312 & .231 & $.081^{* * *}$ & .143 & .160 & $-.017^{* * *}$ \\
\hline \multicolumn{7}{|l|}{ Race } \\
\hline White & .871 & .890 & $-.018^{* * *}$ & .881 & .866 & $.015^{* * *}$ \\
\hline Black & .053 & .036 & $.017^{* * *}$ & .052 & .064 & $-.012^{* * *}$ \\
\hline Other & .075 & .074 & .001 & .067 & .071 & $-.003^{* *}$ \\
\hline Catholic & .321 & .263 & $.058 * * *$ & .303 & .265 & $.039^{* * *}$ \\
\hline Father has a bachelor's degree & .120 & .200 & $-.080 * * *$ & .184 & .222 & $-.039 * * *$ \\
\hline Mother has a bachelor's degree & .118 & .171 & $-.053^{* * *}$ & .155 & .203 & $-.048 * * *$ \\
\hline High-income household & .069 & .171 & $-.103^{* * *}$ & .121 & .184 & $-.063^{* * *}$ \\
\hline Obs. & 12,472 & 132,040 & & 39,337 & 79,888 & \\
\hline
\end{tabular}

Columns (i) and (iv) present the means for those who plan to teach and columns (ii) and (v) for those who plan on non-teaching careers. Columns (iii) and (vi) present the differences between those who plan to teach and others. Survey weights are used to make the statistics nationally representative for first time incoming college students. * indicates significance at the $10 \%$ level, $* *$ at $5 \%$ and ${ }^{* * *}$ at $1 \%$. The p-values correspond to the two-tailed t-test, allowing for unequal variance between groups. 
Table 4: Summary Statistics: Freshmen Who Plan to Teach vs. Freshmen who Plan on Other Careers - 1980 Survey

\begin{tabular}{|c|c|c|c|c|c|c|}
\hline & \multicolumn{3}{|c|}{ Men } & \multicolumn{3}{|c|}{ Women } \\
\hline & $\begin{array}{l}\text { Teach } \\
\text { (i) }\end{array}$ & $\begin{array}{l}\text { Other career plans } \\
\text { (ii) }\end{array}$ & $\begin{array}{l}\text { Difference } \\
\quad \text { (iii) }\end{array}$ & $\begin{array}{l}\text { Teach } \\
\text { (iv) }\end{array}$ & $\begin{array}{l}\text { Other career plans } \\
\qquad(\mathrm{v})\end{array}$ & $\begin{array}{l}\text { Difference } \\
\text { (vi) }\end{array}$ \\
\hline \multicolumn{7}{|l|}{ Academic Ability } \\
\hline High & .350 & .509 & $-.158 * * *$ & .469 & .569 & $-.100 * * *$ \\
\hline Medium & .415 & .315 & $.100^{* * *}$ & .392 & .312 & $.080 * * *$ \\
\hline Low & .234 & .176 & $.058^{* * *}$ & .139 & .119 & $-.020 * * *$ \\
\hline \multicolumn{7}{|l|}{ Race } \\
\hline White & .894 & .856 & $.038^{* * *}$ & .910 & .827 & $.083^{* * *}$ \\
\hline Black & .073 & .076 & -.002 & .061 & .110 & $-.048 * * *$ \\
\hline Other & .033 & .068 & $-.035^{* * *}$ & .029 & .063 & $-.034^{* * *}$ \\
\hline Catholic & .302 & .353 & $-.052^{* * *}$ & .359 & .352 & .007 \\
\hline Father has a bachelor's degree & .169 & .248 & $-.079 * * *$ & .224 & .238 & $-.014^{* * *}$ \\
\hline Mother has a bachelor's degree & .159 & .223 & $.064^{* * *}$ & .197 & .221 & $-.024^{* * *}$ \\
\hline High-income household & .057 & .150 & $-.093^{* * *}$ & .088 & .141 & $-.053 * * *$ \\
\hline Obs. & 1,817 & 95,673 & & 7,658 & 93,504 & \\
\hline
\end{tabular}

Columns (i) and (iv) present the means for those who plan to teach and columns (ii) and (v) for those who plan on non-teaching careers. Columns (iii) and (vi) present the differences between those who plan to teach and others. Survey weights are used to make the statistics nationally representative for first time incoming college students. $*$ indicates significance at the $10 \%$ level, $* *$ at $5 \%$ and $* * *$ at $1 \%$. The p-values correspond to the two-tailed t-test, allowing for unequal variance between groups. 
Table 5: Planning to Teach - Men (CIRP Surveys)

\begin{tabular}{|c|c|c|c|c|}
\hline & \multirow{2}{*}{$\begin{array}{l}\text { All } \\
\text { (i) }\end{array}$} & \multicolumn{3}{|c|}{ By academic ability } \\
\hline & & $\begin{array}{l}\text { high } \\
\text { (ii) }\end{array}$ & $\begin{array}{l}\text { medium } \\
\text { (iii) }\end{array}$ & $\begin{array}{l}\text { low } \\
\text { (iv) }\end{array}$ \\
\hline \multicolumn{5}{|l|}{ Independent variable } \\
\hline Union & $\begin{array}{l}-.004 \\
(.005)\end{array}$ & $\begin{array}{c}-.005^{* *} \\
(.003)\end{array}$ & $\begin{array}{l}-.006 \\
(.008)\end{array}$ & $\begin{array}{l}-.001 \\
(.006)\end{array}$ \\
\hline Pill & $\begin{array}{l}-.004 \\
(.005)\end{array}$ & $\begin{array}{l}-.000 \\
(.003)\end{array}$ & $\begin{array}{l}-.005 \\
(.007)\end{array}$ & $\begin{array}{c}-.012^{* * *} \\
(.004)\end{array}$ \\
\hline Abortion & $\begin{array}{l}-.001 \\
(.003)\end{array}$ & $\begin{array}{c}.005^{* * *} \\
(.002)\end{array}$ & $\begin{array}{l}-.003 \\
(.004)\end{array}$ & $\begin{array}{c}.006 \\
(.006)\end{array}$ \\
\hline Log Relative Wages & $\begin{array}{c}.009 \\
(.008)\end{array}$ & $\begin{array}{c}.003 \\
(.005)\end{array}$ & $\begin{array}{c}.006 \\
(.010)\end{array}$ & $\begin{array}{l}.033^{* *} \\
(.013)\end{array}$ \\
\hline Cohort Size (in 10,000s) & $\begin{array}{c}.001 \\
(.001)\end{array}$ & $\begin{array}{l}.001^{* *} \\
(.000)\end{array}$ & $\begin{array}{c}.001 \\
(.001)\end{array}$ & $\begin{array}{c}.005^{* * *} \\
(.005)\end{array}$ \\
\hline Observations & $1,440,898$ & 644,349 & 487,797 & 308,752 \\
\hline
\end{tabular}

This table shows estimates from a Probit regression where the dependent variable takes value 1 if the student plans for a career in teaching, and 0 otherwise. The reported coefficients are the marginal effects estimated at the mean of the independent variables. Standard errors are robust and clustered by state. ${ }^{*}$ indicates $\mathrm{p}<.10,{ }^{* *} \mathrm{p}<.05$, and ${ }^{* * *} \mathrm{p}<.01$. All specifications include controls for high school grades, college selectivity, race, and for being catholic. Furthermore, all specifications control for state, and cohort fixed effects, and state-specific time trends. 
Table 6: Planning to Teach - Women (CIRP Surveys)

\begin{tabular}{|c|c|c|c|c|}
\hline & \multirow{2}{*}{$\begin{array}{l}\text { All } \\
\\
\text { (i) }\end{array}$} & \multicolumn{3}{|c|}{ By academic ability } \\
\hline & & $\begin{array}{l}\text { high } \\
\text { (ii) }\end{array}$ & $\begin{array}{l}\text { medium } \\
\text { (iii) }\end{array}$ & $\begin{array}{l}\text { low } \\
\text { (iv) }\end{array}$ \\
\hline \multicolumn{5}{|l|}{ Independent variable } \\
\hline Union & $\begin{array}{l}-.008 \\
(.009)\end{array}$ & $\begin{array}{l}-.003 \\
(.013)\end{array}$ & $\begin{array}{l}-.007 \\
(.010)\end{array}$ & $\begin{array}{c}-.017^{* *} \\
(.008)\end{array}$ \\
\hline Pill & $\begin{array}{l}.017^{* *} \\
(.009)\end{array}$ & $\begin{array}{c}.012 \\
(.010)\end{array}$ & $\begin{array}{l}.016^{*} \\
(.009)\end{array}$ & $\begin{array}{c}.029 * * * \\
(.011)\end{array}$ \\
\hline Abortion & $\begin{array}{l}-.009 \\
(.009)\end{array}$ & $\begin{array}{c}.008 \\
(.006)\end{array}$ & $\begin{array}{l}-.008 \\
(.008)\end{array}$ & $\begin{array}{l}-.016 \\
(.012)\end{array}$ \\
\hline Log Relative Wages & $\begin{array}{c}-.026^{* *} \\
(.012)\end{array}$ & $\begin{array}{c}-.026^{* *} \\
(.014)\end{array}$ & $\begin{array}{c}-.028^{* *} \\
(.014)\end{array}$ & $\begin{array}{l}-.021 \\
(.018)\end{array}$ \\
\hline Cohort Size (in 10,000s) & $\begin{array}{l}.002^{*} \\
(.001)\end{array}$ & $\begin{array}{c}.002^{* * *} \\
(.001)\end{array}$ & $\begin{array}{c}.002 \\
(.001)\end{array}$ & $\begin{array}{c}.001 \\
(.003)\end{array}$ \\
\hline Observations & $1,421,304$ & 728,501 & 490,505 & 202,298 \\
\hline
\end{tabular}


Table 7: Effect of Unrestricted Access to the Pill on Men's Career Plans (CIRP Surveys)

\begin{tabular}{|c|c|c|c|c|}
\hline & $\begin{array}{l}\text { All } \\
\text { (i) }\end{array}$ & $\begin{array}{l}\text { High } \\
\text { (ii) }\end{array}$ & $\begin{array}{l}\text { Medium } \\
\text { (iii) }\end{array}$ & $\begin{array}{l}\text { Low } \\
\text { (iv) }\end{array}$ \\
\hline \multicolumn{5}{|l|}{ Dependent variable } \\
\hline Physician $=1$ & $\begin{array}{l}-.005 \\
(.003)\end{array}$ & $\begin{array}{l}-.011 \\
(.008)\end{array}$ & $\begin{array}{l}-.005 \\
(.004)\end{array}$ & $\begin{array}{l}-.002 \\
(.002)\end{array}$ \\
\hline Lawyer $=1$ & $\begin{array}{l}-.003 \\
(.003)\end{array}$ & $\begin{array}{l}-.004 \\
(.006)\end{array}$ & $\begin{array}{l}-.004 \\
(.004)\end{array}$ & $\begin{array}{l}-.002 \\
(.003)\end{array}$ \\
\hline Architect $=1$ & $\begin{array}{l}-.005 \\
(.004)\end{array}$ & $\begin{array}{l}-.002 \\
(.003)\end{array}$ & $\begin{array}{l}-.004 \\
(.006)\end{array}$ & $\begin{array}{l}-.007^{*} \\
(.004)\end{array}$ \\
\hline Business Exec. = 1 & $\begin{array}{c}.003 \\
(.006)\end{array}$ & $\begin{array}{c}.011^{* * *} \\
(.004)\end{array}$ & $\begin{array}{c}.006 \\
(.006)\end{array}$ & $\begin{array}{l}-.003 \\
(.007)\end{array}$ \\
\hline Engineer $=1$ & $\begin{array}{l}-.011 \\
(.013)\end{array}$ & $\begin{array}{l}-.012 \\
(.019)\end{array}$ & $\begin{array}{l}-.005 \\
(.017)\end{array}$ & $\begin{array}{l}-.001 \\
(.011)\end{array}$ \\
\hline Business Owner $=1$ & $\begin{array}{c}.003^{* * *} \\
(.001)\end{array}$ & $\begin{array}{c}.001 \\
(.001)\end{array}$ & $\begin{array}{c}.006^{* * *} \\
(.001)\end{array}$ & $\begin{array}{c}.004^{* * *} \\
(.001)\end{array}$ \\
\hline Accountant $=1$ & $\begin{array}{l}.010^{* *} \\
(.004)\end{array}$ & $\begin{array}{l}.009^{*} \\
(.005)\end{array}$ & $\begin{array}{c}.007 \\
(.006)\end{array}$ & $\begin{array}{c}.014^{* * *} \\
(.004)\end{array}$ \\
\hline Scientific Res. $=1$ & $\begin{array}{l}-.004^{*} \\
(.002)\end{array}$ & $\begin{array}{l}-.009^{*} \\
(.005)\end{array}$ & $\begin{array}{l}-.001 \\
(.002)\end{array}$ & $\begin{array}{l}-.003 \\
(.002)\end{array}$ \\
\hline Computer Prog. $=1$ & $\begin{array}{c}.003 \\
(.003)\end{array}$ & $\begin{array}{c}.000 \\
(.003)\end{array}$ & $\begin{array}{c}.002 \\
(.003)\end{array}$ & $\begin{array}{c}.001 \\
(.003)\end{array}$ \\
\hline Observations & $1,587,037$ & 668,142 & 545,602 & 373,292 \\
\hline
\end{tabular}

The reported estimates are the estimated probit coefficients. Standard errors are robust and clustered by state. ${ }^{*}$ indicates $\mathrm{p}<.10,{ }^{* *} \mathrm{p}<.05$, and ${ }^{* * *} \mathrm{p}<.01$. All specifications include controls for high school grades, college selectivity, race, and for being catholic. Furthermore, all specifications control for state, and cohort fixed effects, and state-specific time trends. 
Table 8: Effect of Unrestricted Access to the Pill on Women's Career Plans (CIRP Surveys)

\begin{tabular}{|c|c|c|c|c|}
\hline & $\begin{array}{l}\text { All } \\
\text { (i) }\end{array}$ & $\begin{array}{l}\text { High Ability } \\
\text { (ii) }\end{array}$ & $\begin{array}{c}\text { Medium Ability } \\
\text { (iii) }\end{array}$ & $\begin{array}{c}\text { Low Ability } \\
\text { (iv) }\end{array}$ \\
\hline \multicolumn{5}{|l|}{ Dependent variable } \\
\hline \multirow[t]{2}{*}{ Physician $=1$} & -.002 & -.007 & -.001 & .001 \\
\hline & $(.001)$ & $(.005)$ & $(.001)$ & $(.001)$ \\
\hline \multirow[t]{2}{*}{ Lawyer $=1$} & -.001 & -.006 & .000 & .002 \\
\hline & $(.001)$ & $(.004)$ & $(.001)$ & $(.002)$ \\
\hline \multirow[t]{2}{*}{ Business Exec. $=1$} & .001 & $.004^{* *}$ & .001 & -.002 \\
\hline & $(.003)$ & $(.002)$ & $(.004)$ & $(.006)$ \\
\hline \multirow[t]{2}{*}{ Accountant $=1$} & .005 & .001 & $.006^{* *}$ & $.009 * * *$ \\
\hline & $(.004)$ & $(.004)$ & $(.003)$ & $(.004)$ \\
\hline \multirow[t]{2}{*}{ Artist $=1$} & -.003 & -.001 & -.005 & .002 \\
\hline & $(.003)$ & $(.002)$ & $(.003)$ & $(.006)$ \\
\hline \multirow[t]{2}{*}{ Lab Techn. $=1$} & -.004 & -.003 & $-.007^{*}$ & -.002 \\
\hline & $(.003)$ & $(.003)$ & $(.004)$ & $(.003)$ \\
\hline \multirow[t]{2}{*}{ Computer Prog. $=1$} & -.000 & -.002 & .000 & .000 \\
\hline & $(.002)$ & $(.003)$ & $(.002)$ & $(.002)$ \\
\hline \multirow[t]{2}{*}{ Therapist $=1$} & -.004 & .003 & $-.007^{*}$ & -.002 \\
\hline & $(.003)$ & $(.003)$ & $(.004)$ & $(.003)$ \\
\hline \multirow[t]{2}{*}{ Social Worker $=1$} & -.002 & .000 & -.001 & -.005 \\
\hline & $(.002)$ & $(.001)$ & $(.002)$ & $(.005)$ \\
\hline \multirow[t]{2}{*}{ Nurse $=1$} & -.007 & .003 & -.012 & -.013 \\
\hline & $(.008)$ & $(.007)$ & $(.010)$ & $(.009)$ \\
\hline \multirow[t]{2}{*}{ Clerical $=1$} & .004 & .003 & .004 & .007 \\
\hline & $(.004)$ & $(.002)$ & $(.007)$ & $(.008)$ \\
\hline \multirow[t]{2}{*}{ Homemaker $=1$} & -.002 & -.001 & -.002 & -.002 \\
\hline & $(.002)$ & $(.001)$ & $(.003)$ & $(.007)$ \\
\hline Observations & $1,539,136$ & 756,389 & 548,841 & 233,906 \\
\hline
\end{tabular}

The reported estimates are the estimated probit coefficients. Standard errors are robust and clustered by state. ${ }^{*}$ indicates $\mathrm{p}<.10,{ }^{* *} \mathrm{p}<.05$, and ${ }^{* * *} \mathrm{p}<.01$. All specifications include controls for high school grades, college selectivity, race, and for being catholic. Furthermore, all specifications control for state, and cohort fixed effects, and state-specific time trends. 
Table 9: Impact on Becoming a Teacher (Census Data)

\begin{tabular}{lcc}
\hline \hline & Men & Women \\
& $(\mathrm{i})$ & $(\mathrm{ii})$ \\
\hline Dependent variable & & \\
& & \\
Union & .002 & -.004 \\
Pill & $(.002)$ & $(.004)$ \\
& $-.002^{* *}$ & $.004^{* *}$ \\
Abortion & $(.001)$ & $(.002)$ \\
& -.001 & $-.010^{* * *}$ \\
Log Relative Wages & $(.002)$ & $(.003)$ \\
& $-.009^{* * *}$ & -.007 \\
Observations & $(.003)$ & $(.005)$ \\
\hline
\end{tabular}

The reported estimates are the estimated probit coefficients. Standard errors are robust and clustered by state. ${ }^{*}$ indicates $\mathrm{p}<.10,{ }^{* *} \mathrm{p}<.05$, and ${ }^{* * *} \mathrm{p}<.01$. All specifications include controls for race, and for being catholic. Furthermore, all specifications control for state, and cohort fixed effects, and state-specific time trends. 
Table 10: Effect of Unrestricted Access to the Pill on Other Careers (Census Data)

\begin{tabular}{lcc}
\hline \hline & Men & Women \\
& $(\mathrm{i})$ & $(\mathrm{ii})$ \\
\hline Dependent variable & & \\
Physician $=1$ & .000 & .000 \\
Lawyer $=1$ & $(.000)$ & $(.000)$ \\
Business Exec. $=1$ & -.001 & .000 \\
Accountant $=1$ & $(.001)$ & $(.000)$ \\
Engineer $=1$ & $.002^{*}$ & .001 \\
Scientific Researcher $=1$ & $(.001)$ & $. .001)$ \\
& .001 & .000 \\
Nurse $=1$ & $(.001)$ & $.000)$ \\
& $.003^{* *}$ & .000 \\
Observations & $(.001)$ & $.000)$ \\
\hline
\end{tabular}

The reported estimates are the estimated probit coefficients. Standard errors are robust and clustered by state. ${ }^{*}$ indicates $\mathrm{p}<.10{ }^{* *} \mathrm{p}<.05$, and ${ }^{* * *} \mathrm{p}<.01$. All specifications include controls for race, and for being catholic. Furthermore, all specifications control for state, and cohort fixed effects, and state-specific time trends. 
Table A.1: Years of Legal Changes Granting Early Legal Access to the Pill (from Myers (2017))

\begin{tabular}{|c|c|c|c|}
\hline State & Year of Law Change & State & Year of Law Change \\
\hline Alabama & 1971 (MCL) & Montana & $1960(\mathrm{AOM})$ \\
\hline Alaska & $1960(\mathrm{AOM})$ & Nebraska & $1972(\mathrm{AOM})$ \\
\hline Arizona & $1972(\mathrm{AOM})$ & Nevada & $1963(\mathrm{AOM})$ \\
\hline Arkansas & $1960(\mathrm{AOM})$ & New Hampshire & $1971(\mathrm{MM})$ \\
\hline California & $1972(\mathrm{AOM})$ & New Jersey & $1973(\mathrm{AOM})$ \\
\hline Colorado & 1971 (MCL) & New Mexico & $1973(\mathrm{AOM})$ \\
\hline Connecticut & 1971 (MCL) & New York & 1971 (MCL) \\
\hline Delaware & 1971 (MCL) & North Carolina & 1971 (AOM) \\
\hline District of Columbia & 1971 (MCL) & North Dakota & $1960(\mathrm{AOM})$ \\
\hline Florida & $1972(\mathrm{HH})$ & Ohio & $1965(\mathrm{MM})$ \\
\hline Georgia & 1971 (MCL) & Oklahoma & $1960(\mathrm{AOM})$ \\
\hline Hawaii & $1972(\mathrm{AOM})$ & Oregon & 1971 (MCL) \\
\hline Idaho & $1960(\mathrm{AOM})$ & Pennsylvania & $1970(\mathrm{MCL})$ \\
\hline Illinois & $1961(\mathrm{AOM})$ & Rhode Island & $1972(\mathrm{AOM})$ \\
\hline Indiana & $1973(\mathrm{AOM})$ & South Carolina & $1972(\mathrm{MCL})$ \\
\hline Iowa & $1972(\mathrm{AOM})$ & South Dakota & $1972(\mathrm{AOM})$ \\
\hline Kansas & $1970(\mathrm{MM})$ & Tennessee & 1971 (AOM) \\
\hline Kentucky & $1965(\mathrm{AOM})$ & Texas & $1973(\mathrm{AOM})$ \\
\hline Louisiana & $1972(\mathrm{AOM})$ & Utah & $1960(\mathrm{AOM})$ \\
\hline Maine & $1972(\mathrm{AOM})$ & Vermont & 1971 (AOM) \\
\hline Maryland & 1971 (MCL) & Virginia & 1971 (MCL) \\
\hline Massachusetts & $1974(\mathrm{AOM})$ & Washington & 1970 (MCL) \\
\hline Michigan & $1972(\mathrm{AOM})$ & West Virginia & $1972(\mathrm{AOM})$ \\
\hline Minnesota & $1973(\mathrm{AOM})$ & Wisconsin & $1974(\mathrm{AOM})^{*}$ \\
\hline Missisippi & $1965(\mathrm{MM})$ & Wyoming & $1973(\mathrm{AOM})$ \\
\hline Missouri & 1977 (MCL) & & \\
\hline
\end{tabular}

The table lists the date of legal change, i.e., the earliest year in which unmarried, childless women under age 21 could legally obtain medical treatment without parental or spousal consent. AOM: age of majority, implies statutory change in the legal AOM from 21 to 18 or 19. MCL: medical consent law, denotes an enactment of an MCL granting unmarried minors the capacity to consent. MM: mature minor, denotes an MM doctrine that allowed legal minors to consent to medical care as long as they were mature enough to understand "the nature and the consequences of the treatment." HH: health hazard, refers to laws that permitted physicians to provide the relevant services if they believed that failure to do so could be hazardous to the minor's health. *Wisconsin lowered the age of majority in 1972, but enforced a Comstock law, prohibiting the sale of contraception to unmarried people, until 1974. 
Table A.2: Years of Legal Changes Granting Early Legal Access to Abortion (from Myers, 2017)

\begin{tabular}{llll}
\hline \hline State & Year of Law Change & State & Year of Law Change \\
\hline Alabama & 1973 & Montana & 1973 \\
Alaska & $1970(\mathrm{PIL})$ & Nebraska & 1973 \\
Arizona & 1973 & Nevada & 1973 \\
Arkansas & 1973 & New Hampshire & 1973 \\
California & $1971(\mathrm{JR})$ & New Jersey & 1973 \\
Colorado & 1973 & New Mexico & 1973 \\
Connecticut & 1973 & New York & $1970^{*}$ \\
Delaware & 1973 & North Carolina & 1973 \\
District of Columbia & 1973 & North Dakota & $1974(\mathrm{AOM})$ \\
Florida & 1973 & Ohio & 1973 \\
Georgia & 1973 & Oklahoma & 1973 \\
Hawaii & $1970(\mathrm{MCL})$ & Oregon & 1973 \\
Idaho & 1973 & Pennsylvania & 1973 \\
Illinois & 1973 & Rhode Island & 1973 \\
Indiana & 1973 & South Carolina & $1974(\mathrm{PIL})$ \\
Iowa & 1973 & South Dakota & 1973 \\
Kansas & 1973 & Tennessee & 1973 \\
Kentucky & 1973 & Texas & 1973 \\
Louisiana & 1973 & Utah & 1973 \\
Maine & 1973 & Vermont & 1973 \\
Maryland & 1973 & Virginia & 1973 \\
Massachusetts & $1974($ AOM $)$ & Washington & 1970 (MCL + PIL) \\
Michigan & 1973 & West Virginia & 1973 \\
Minnesota & 1973 & Wisconsin & 1973 \\
Mississippi & 1973 & Wyoming & 1973 \\
Missouri & $1974(\mathrm{PIL})$ & & \\
\hline & & &
\end{tabular}

The table lists the date of legal change, i.e., the earliest year, in which unmarried childless women under age 21 could legally get an abortion without parental or spousal consent. AOM: age of majority, implies statutory change in the legal AOM from 21 to 18 or 19. MCL: medical consent law, denotes an enactment of a MCL granting unmarried minors the capacity to consent. PIL: parental involvement law, refers to PIL stating a minimum age to consent that is below the age of majority, JR: judical rulings, enjoin enforcement of a restrictive law.

*New York City hospitals performed abortions on minors aged 17 and older without parental consent. 
Table A.3: Changes in Union Laws (Hoxby, 2004)

\begin{tabular}{lccclccc}
\hline \hline State & Rights & Shop & Agency & State & Rights & Shop & Agency \\
\hline Alabama & - & - & - & Montana & 1972 & 1976 & - \\
Alaska & 1971 & - & - & Nebraska & - & - & - \\
Arizona & - & - & - & Nevada & 1970 & - & - \\
Arkansas & - & - & - & New Hampshire & 1976 & - & - \\
California & 1977 & 1977 & - & New Jersey & 1969 & 1981 & - \\
Colorado & - & - & - & New Mexico & - & - & - \\
Connecticut & 1966 & 1980 & - & New York & 1968 & 1978 & - \\
Delaware & 1970 & - & - & North Carolina & - & - & - \\
Florida & 1976 & - & - & North Dakota & 1970 & - & - \\
Georgia & - & - & - & Ohio & 1985 & 1978 & - \\
Hawaii & 1971 & 1971 & - & Oklahoma & 1972 & - & - \\
Idaho & 1972 & - & - & Oregon & 1970 & 1974 & $1974-1977$ \\
Illinois & 1985 & 1985 & - & Pennsylvania & 1971 & - & - \\
Indiana & 1974 & 1984 & - & Rhode Island & 1967 & 1976 & - \\
Iowa & 1976 & - & - & South Carolina & - & - & - \\
Kansas & 1971 & - & - & South Dakota & 1971 & - & - \\
Kentucky & - & - & - & Tennessee & 1979 & - & - \\
Louisiana & - & - & - & Texas & - & - & - \\
Maine & 1970 & - & - & Utah & - & - & - \\
Maryland & 1970 & - & - & Vermont & 1968 & $1968-1969$ & $1968-1969$ \\
Massachusetts & 1966 & - & - & Virginia & - & - & - \\
Michigan & 1966 & - & - & Washington & 1968 & 1974 & $1974-1976$ \\
Minnesota & 1973 & - & - & West Virginia & - & - & - \\
Mississippi & - & - & - & Wisconsin & 1960 & 1972 & - \\
Missouri & - & - & - & Wyoming & - & - & - \\
\hline The & & - & - & - & - & - \\
\end{tabular}

The table lists the year each state passed a law that facilitated teachers' unionization. Rights refers to laws that extended collective bargaining rights to teachers' unions. For some states it was limited to the right to organize for collective bargaining while in other states teachers' unions obtained the right to meet with administration representatives. Shop means that the state passed a law allowing teachers' unions to have union shops and Agency if the state allowed agency shops. Union shop exists if the school district cannot employ teachers who are not union members, and a union is said to have an agency shop if it collects dues from all teachers in the bargaining unit, regardless of whether they are union members. 


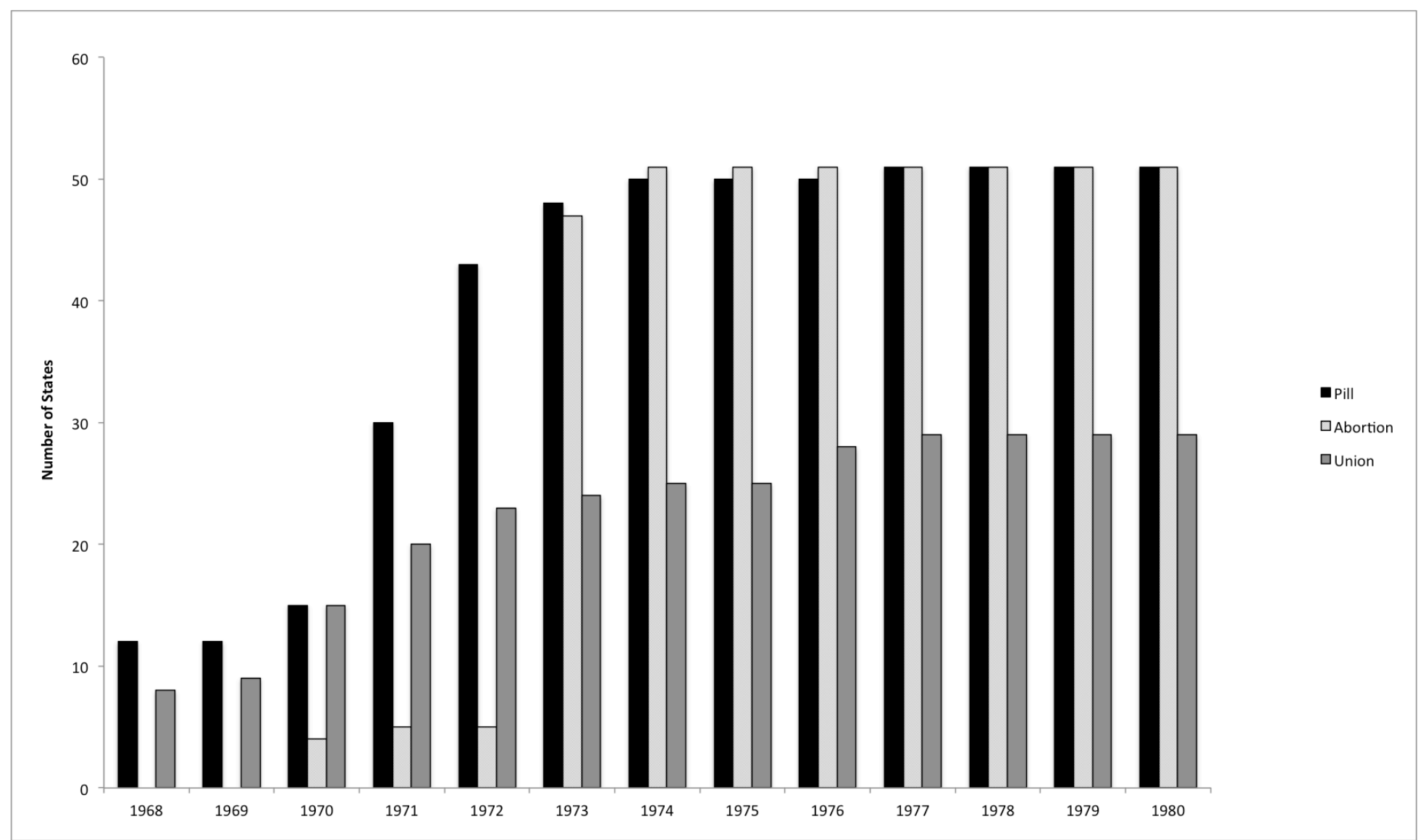

Figure A.1: Number of states to adopt law changes by year 


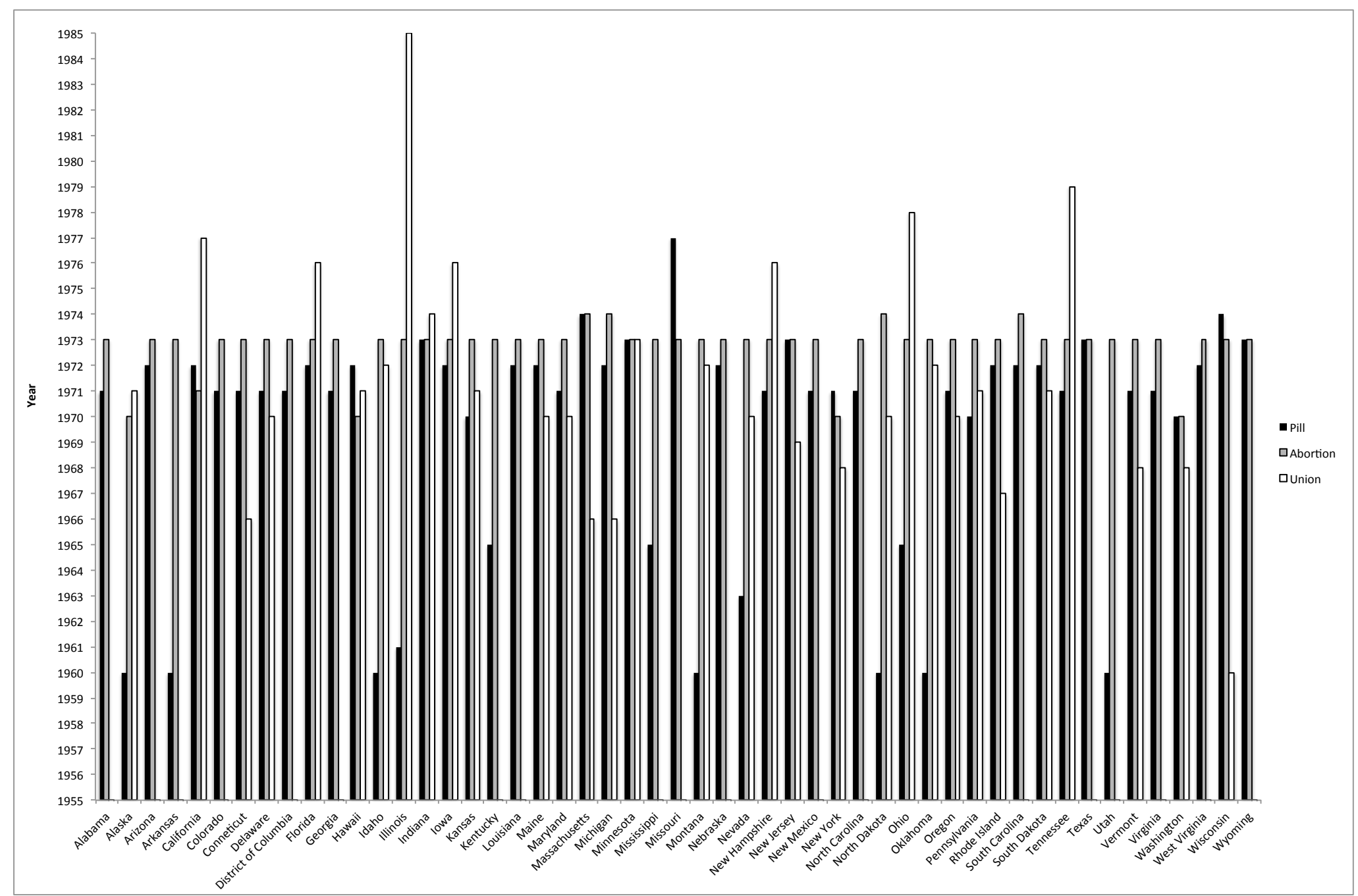

Figure A.2: Years when laws where adopted for each state 
Table A.4: Plans to Teach, Logit Estimates (CIRP Surveys)

\begin{tabular}{|c|c|c|c|c|c|c|}
\hline \multirow[b]{2}{*}{ Independent variable } & \multicolumn{3}{|c|}{ Men } & \multicolumn{3}{|c|}{ Women } \\
\hline & $\begin{array}{l}\text { (i) } \\
\text { high }\end{array}$ & $\begin{array}{c}\text { (ii) } \\
\text { medium }\end{array}$ & $\begin{array}{l}\text { (iii) } \\
\text { low }\end{array}$ & $\begin{array}{l}\text { (iv) } \\
\text { high }\end{array}$ & $\begin{array}{c}(\mathrm{v}) \\
\text { medium }\end{array}$ & $\begin{array}{l}\text { (vi) } \\
\text { low }\end{array}$ \\
\hline Union & $\begin{array}{l}-.005^{*} \\
(.003)\end{array}$ & $\begin{array}{c}.001 \\
(.004)\end{array}$ & $\begin{array}{l}-.000 \\
(.005)\end{array}$ & $\begin{array}{l}-.003 \\
(.013)\end{array}$ & $\begin{array}{l}-.007 \\
(.010)\end{array}$ & $\begin{array}{c}-.017^{* *} \\
(.008)\end{array}$ \\
\hline Pill & $\begin{array}{c}.000 \\
(.003)\end{array}$ & $\begin{array}{l}-.004 \\
(.006)\end{array}$ & $\begin{array}{c}-.011^{* * *} \\
(.004)\end{array}$ & $\begin{array}{c}.012 \\
(.010)\end{array}$ & $\begin{array}{l}.016^{*} \\
(.009)\end{array}$ & $\begin{array}{c}.029 * * * \\
(.011)\end{array}$ \\
\hline Abortion & $\begin{array}{c}.005^{* * *} \\
(.002)\end{array}$ & $\begin{array}{l}-.002 \\
(.004)\end{array}$ & $\begin{array}{c}.006 \\
(.005)\end{array}$ & $\begin{array}{c}.008 \\
(.006)\end{array}$ & $\begin{array}{l}-.008 \\
(.008)\end{array}$ & $\begin{array}{l}-.016 \\
(.012)\end{array}$ \\
\hline Log Relative Wages & $\begin{array}{c}.002 \\
(.005)\end{array}$ & $\begin{array}{c}.007 \\
(.010)\end{array}$ & $\begin{array}{l}.031^{* *} \\
(.013)\end{array}$ & $\begin{array}{c}.008 \\
(.014)\end{array}$ & $\begin{array}{l}-.008 \\
(.014)\end{array}$ & $\begin{array}{l}-.016 \\
(.018)\end{array}$ \\
\hline Cohort Size (in 10,000s) & $\begin{array}{l}.001^{* *} \\
(.000)\end{array}$ & $\begin{array}{c}.001 \\
(.001)\end{array}$ & $\begin{array}{c}.005^{* * *} \\
(.001)\end{array}$ & $\begin{array}{c}.002^{* * *} \\
(.001)\end{array}$ & $\begin{array}{c}.002 \\
(.001)\end{array}$ & $\begin{array}{c}.001 \\
(.003)\end{array}$ \\
\hline Observations & 644,349 & 487,797 & 308,752 & 728,501 & 490,505 & 202,298 \\
\hline
\end{tabular}

The Table shows estimates from a logit regression where the dependent variable takes value 1 if the student plans for a career in teaching, and 0 otherwise. The reported coefficients are the marginal effects estimated at the mean of the independent variables. Standard errors are robust and clustered by state. ${ }^{*}$ indicates $\mathrm{p}<.10,{ }^{* *} \mathrm{p}<.05$, and ${ }^{* * *} \mathrm{p}<.01$. All specifications include controls for high school grades, college selectivity, race, and for being catholic. Furthermore, all specifications control for state, and cohort fixed effects, and state-specific time trends. 
Table A.5: Plans to Teach - Using Alternative Coding for ELA to Pill, from Bailey et al., 2011 (CIRP Surveys)

\begin{tabular}{|c|c|c|c|c|c|c|}
\hline \multirow[b]{2}{*}{ Independent variable } & \multicolumn{3}{|c|}{ Men } & \multicolumn{3}{|c|}{ Women } \\
\hline & $\begin{array}{c}\text { (i) } \\
\text { high }\end{array}$ & $\begin{array}{c}\text { (ii) } \\
\text { medium }\end{array}$ & $\begin{array}{l}\text { (iii) } \\
\text { low }\end{array}$ & $\begin{array}{l}\text { (iv) } \\
\text { high }\end{array}$ & $\begin{array}{c}(\mathrm{v}) \\
\text { medium }\end{array}$ & $\begin{array}{l}\text { (vi) } \\
\text { low }\end{array}$ \\
\hline Union & $\begin{array}{l}-.004 \\
(.003)\end{array}$ & $\begin{array}{l}-.006 \\
(.008)\end{array}$ & $\begin{array}{l}-.000 \\
(.013)\end{array}$ & $\begin{array}{l}-.000 \\
(.009)\end{array}$ & $\begin{array}{l}-.006 \\
(.010)\end{array}$ & $\begin{array}{c}-.018 * * \\
(.007)\end{array}$ \\
\hline Pill & $\begin{array}{l}-.004 \\
(.003)\end{array}$ & $\begin{array}{l}-.003 \\
(.009)\end{array}$ & $\begin{array}{l}-.007 \\
(.011)\end{array}$ & $\begin{array}{l}-.007 \\
(.009)\end{array}$ & $\begin{array}{c}.003 \\
(.010)\end{array}$ & $\begin{array}{c}.028 * * * \\
(.009)\end{array}$ \\
\hline Abortion & $\begin{array}{c}.006^{* * *} \\
(.002)\end{array}$ & $\begin{array}{l}-.003 \\
(.005)\end{array}$ & $\begin{array}{l}-.005 \\
(.008)\end{array}$ & $\begin{array}{l}.013^{*} \\
(.007)\end{array}$ & $\begin{array}{l}-.004 \\
(.008)\end{array}$ & $\begin{array}{l}-.018 \\
(.012)\end{array}$ \\
\hline Log Relative Wages & $\begin{array}{c}.004 \\
(.005)\end{array}$ & $\begin{array}{c}.007 \\
(.010)\end{array}$ & $\begin{array}{c}.016 \\
(.012)\end{array}$ & $\begin{array}{c}-.025^{*} \\
(.014)\end{array}$ & $\begin{array}{c}-.028^{* *} \\
(.014)\end{array}$ & $\begin{array}{l}-.021 \\
(.018)\end{array}$ \\
\hline Cohort Size (in 10,000s) & $\begin{array}{l}.001^{* *} \\
(.000)\end{array}$ & $\begin{array}{c}.001 \\
(.001)\end{array}$ & $\begin{array}{c}.001 \\
(.001)\end{array}$ & $\begin{array}{l}.002^{* *} \\
(.001)\end{array}$ & $\begin{array}{c}.002 \\
(.001)\end{array}$ & $\begin{array}{c}.001 \\
(.003)\end{array}$ \\
\hline Observations & 644,349 & 487,797 & 308,752 & 728,501 & 490,505 & 202,298 \\
\hline
\end{tabular}

This table shows estimates from a probit regression where the dependent variable takes value 1 if the student plans for a career in teaching, and 0 otherwise. The reported coefficients are the marginal effects estimated at the mean of the independent variables.. Standard errors are robust and clustered by state. ${ }^{*}$ indicates $\mathrm{p}<.10,{ }^{* *} \mathrm{p}<.05$, and ${ }^{* * *} \mathrm{p}<.01$. All specifications include controls for high school grades, college selectivity, race, and for being catholic. Furthermore, all specifications control for state, and cohort fixed effects, and state-specific time trends. 
Table A.6: Plans to Teach - Only including 1973-1980 (CIRP Surveys)

\begin{tabular}{|c|c|c|c|c|c|c|}
\hline \multirow[b]{2}{*}{ Independent variable } & \multicolumn{3}{|c|}{ Men } & \multicolumn{3}{|c|}{ Women } \\
\hline & $\begin{array}{c}\text { (i) } \\
\text { high }\end{array}$ & $\begin{array}{c}\text { (ii) } \\
\text { medium }\end{array}$ & $\begin{array}{l}\text { (iii) } \\
\text { low }\end{array}$ & $\begin{array}{l}\text { (iv) } \\
\text { high }\end{array}$ & $\begin{array}{c}(\mathrm{v}) \\
\text { medium }\end{array}$ & $\begin{array}{l}\text { (vi) } \\
\text { low }\end{array}$ \\
\hline Union & $\begin{array}{l}-.004 \\
(.002)\end{array}$ & $\begin{array}{c}.001 \\
(.003)\end{array}$ & $\begin{array}{l}-.002 \\
(.006)\end{array}$ & $\begin{array}{c}.001 \\
(.017)\end{array}$ & $\begin{array}{l}-.007 \\
(.009)\end{array}$ & $\begin{array}{c}-.019^{* * *} \\
(.005)\end{array}$ \\
\hline Pill & $\begin{array}{l}-.000 \\
(.004)\end{array}$ & $\begin{array}{c}.000 \\
(.004)\end{array}$ & $\begin{array}{c}-.010^{* *} \\
(.005)\end{array}$ & $\begin{array}{l}-.004 \\
(.006)\end{array}$ & $\begin{array}{c}.034^{* * *} \\
(.010)\end{array}$ & $\begin{array}{c}.021 \\
(.013)\end{array}$ \\
\hline Abortion & $\begin{array}{c}.002 \\
(.004)\end{array}$ & $\begin{array}{c}.000 \\
(.004)\end{array}$ & $\begin{array}{c}.006 \\
(.006)\end{array}$ & $\begin{array}{c}.002 \\
(.012)\end{array}$ & $\begin{array}{l}-.002 \\
(.013)\end{array}$ & $\begin{array}{c}.000 \\
(.020)\end{array}$ \\
\hline Log Relative Wages & $\begin{array}{c}.009 \\
(.006)\end{array}$ & $\begin{array}{c}.005 \\
(.008)\end{array}$ & $\begin{array}{c}.007 \\
(.006)\end{array}$ & $\begin{array}{l}-.001 \\
(.018)\end{array}$ & $\begin{array}{l}-.014 \\
(.014)\end{array}$ & $\begin{array}{l}-.030 \\
(.017)\end{array}$ \\
\hline Cohort Size (in 10,000s) & $\begin{array}{c}.000 \\
(.000)\end{array}$ & $\begin{array}{l}-.000 \\
(.001)\end{array}$ & $\begin{array}{c}-.001^{* * *} \\
(.000)\end{array}$ & $\begin{array}{c}.001 \\
(.001)\end{array}$ & $\begin{array}{l}-.000 \\
(.001)\end{array}$ & $\begin{array}{c}-.004^{* * *} \\
(.001)\end{array}$ \\
\hline Observations & 481,263 & 228,769 & 271,718 & 561,430 & 368,723 & 146,455 \\
\hline
\end{tabular}

The Table shows estimates from a probit regression where the dependent variable takes value 1 if the student plans for a career in teaching, and 0 otherwise. The reported coefficients are the marginal effects estimated at the mean of the independent variables. Standard errors are robust and clustered by state. ${ }^{*}$ indicates $\mathrm{p}<.10,{ }^{* *} \mathrm{p}<.05$, and ${ }^{* * *} \mathrm{p}<.01$. All specifications include controls for high school grades, college selectivity, race, and for being catholic. Furthermore, all specifications control for state, and cohort fixed effects, and state-specific time trends. 
Table A.7: Plans to Teach - Men by Academic Ability (CIRP Surveys)

\begin{tabular}{|c|c|c|c|c|c|c|}
\hline \multirow[b]{2}{*}{ Independent variable } & \multicolumn{3}{|c|}{ College Selectivity } & \multicolumn{3}{|c|}{ High School Grades } \\
\hline & $\begin{array}{l}\text { (i) } \\
\text { high }\end{array}$ & $\begin{array}{c}\text { (ii) } \\
\text { medium }\end{array}$ & $\begin{array}{l}\text { (iii) } \\
\text { low }\end{array}$ & $\begin{array}{l}\text { (iv) } \\
\text { high }\end{array}$ & $\begin{array}{c}(\mathrm{v}) \\
\text { medium }\end{array}$ & $\begin{array}{l}\text { (vi) } \\
\text { low }\end{array}$ \\
\hline Union & $\begin{array}{c}.002 \\
(.006)\end{array}$ & $\begin{array}{l}-.013 \\
(.013)\end{array}$ & $\begin{array}{l}-.004 \\
(.005)\end{array}$ & $\begin{array}{l}-.003 \\
(.003)\end{array}$ & $\begin{array}{l}-.004 \\
(.005)\end{array}$ & $\begin{array}{l}-.004 \\
(.007)\end{array}$ \\
\hline Pill & $\begin{array}{c}-.008^{* *} \\
(.004)\end{array}$ & $\begin{array}{c}.005 \\
(.013)\end{array}$ & $\begin{array}{c}-.011^{* * *} \\
(.003)\end{array}$ & $\begin{array}{l}-.004 \\
(.003)\end{array}$ & $\begin{array}{l}-.004 \\
(.005)\end{array}$ & $\begin{array}{l}-.008 \\
(.007)\end{array}$ \\
\hline Abortion & $\begin{array}{c}.011^{* * *} \\
(.002)\end{array}$ & $\begin{array}{l}-.003 \\
(.008)\end{array}$ & $\begin{array}{c}.003 \\
(.004)\end{array}$ & $\begin{array}{l}.004^{* *} \\
(.002)\end{array}$ & $\begin{array}{l}-.001 \\
(.003)\end{array}$ & $\begin{array}{l}-.002 \\
(.006)\end{array}$ \\
\hline Log Relative Wages & $\begin{array}{c}.004 \\
(.006)\end{array}$ & $\begin{array}{c}.024 \\
(.201)\end{array}$ & $\begin{array}{c}.017 \\
(.011)\end{array}$ & $\begin{array}{c}.004 \\
(.006)\end{array}$ & $\begin{array}{c}.007 \\
(.009)\end{array}$ & $\begin{array}{c}.019 \\
(.013)\end{array}$ \\
\hline Cohort Size (in $10,000 \mathrm{~s}$ ) & $\begin{array}{c}.001 \\
(.001)\end{array}$ & $\begin{array}{c}.000 \\
(.001)\end{array}$ & $\begin{array}{l}-.001 \\
(.001)\end{array}$ & $\begin{array}{c}.001 \\
(.001)\end{array}$ & $\begin{array}{c}.001 \\
(.001)\end{array}$ & $\begin{array}{c}.004 \\
(.002)\end{array}$ \\
\hline Observations & 576,090 & 323,358 & 577,705 & 350,282 & 822,460 & 273,460 \\
\hline
\end{tabular}

The dependent variable takes value 1 if the student plans for a career in teaching, and 0 otherwise. The reported estimates are the estimated probit coefficients. Standard errors are robust and clustered by state. ${ }^{*}$ indicates $\mathrm{p}<.10, * * \mathrm{p}<.05$, and ${ }^{* * *} \mathrm{p}<.01$. All specifications include controls for high school grades, college selectivity, race, and for being catholic. Furthermore, all specifications control for state, and cohort fixed effects, and state specific time trends. 
Table A.8: Plans to Teach - Women by Academic ability (CIRP Surveys)

\begin{tabular}{|c|c|c|c|c|c|c|}
\hline \multirow{3}{*}{ Independent variable } & \multicolumn{3}{|c|}{ College Selectivity } & \multicolumn{3}{|c|}{ High School Grades } \\
\hline & (i) & (ii) & (iii) & (iv) & $(\mathrm{v})$ & (vi) \\
\hline & high & medium & low & high & medium & low \\
\hline \multirow[t]{2}{*}{ Union } & .021 & -.004 & -.006 & -.004 & -.005 & $-.028 * * *$ \\
\hline & $(.025)$ & $(.013)$ & $(.007)$ & $(.008)$ & $(.011)$ & $(.009)$ \\
\hline \multirow[t]{2}{*}{ Pill } & -.015 & $.050^{* *}$ & $.021^{*}$ & $.018^{*}$ & $.016^{*}$ & $.026^{* *}$ \\
\hline & $(.011)$ & $(.023)$ & $(.011)$ & $(.011)$ & $(.009)$ & $(.012)$ \\
\hline \multirow[t]{2}{*}{ Abortion } & .035 & -.005 & $-.019^{*}$ & -.001 & -.004 & -.010 \\
\hline & $(.011)$ & $(.023)$ & $(.011)$ & $(.006)$ & $(.007)$ & $(.013)$ \\
\hline \multirow[t]{2}{*}{ Log Relative Wages } & $-.041^{*}$ & -.010 & -.020 & $-.022^{*}$ & $-.025^{*}$ & $-.031^{*}$ \\
\hline & $(.024)$ & $(.022)$ & $(.016)$ & $(.012)$ & $(.014)$ & $(.017)$ \\
\hline \multirow[t]{2}{*}{ Cohort Size (in $10,000 \mathrm{~s}$ ) } & -.003 & .002 & .000 & .001 & .001 & .002 \\
\hline & $(.003)$ & $(.002)$ & $(.003)$ & $(.001)$ & $(.001)$ & $(.002)$ \\
\hline Observations & 480,193 & 353,057 & 614,602 & 454,446 & 830,781 & 147,192 \\
\hline
\end{tabular}

The dependent variable takes value 1 if the student plans for a career in teaching, and 0 otherwise. The reported estimates are the estimated probit coefficients. Standard errors are robust and clustered by state. ${ }^{*}$ indicates $\mathrm{p}<.10, * * \mathrm{p}<.05$, and ${ }^{* * *} \mathrm{p}<.01$. All specifications include controls for high school grades, college selectivity, race, and for being catholic. Furthermore, all specifications control for state, and cohort fixed effects, and state-specific time trend. 
Table A.9: Plans to Teach - Alternative Wage Measures - Men (CIRP Surveys)

\begin{tabular}{|c|c|c|c|c|c|c|}
\hline \multirow{3}{*}{ Independent variable } & \multicolumn{3}{|c|}{ Relative wages: $25-50$ year olds } & \multicolumn{3}{|c|}{ Relative wages: $30-55$ year olds } \\
\hline & (i) & (ii) & (iii) & (iv) & $(\mathrm{v})$ & (vi) \\
\hline & high & medium & low & high & medium & low \\
\hline \multirow[t]{2}{*}{ Union } & $-.005^{*}$ & -.006 & .000 & $-.005^{*}$ & -.006 & .000 \\
\hline & $(.003)$ & $(.007)$ & $(.009)$ & $(.002)$ & $(.007)$ & $(.006)$ \\
\hline \multirow[t]{2}{*}{ Pill } & -.001 & -.005 & $-.013^{* * *}$ & -.001 & -.005 & $-.013^{* * *}$ \\
\hline & $(.003)$ & $(.007)$ & $(.004)$ & $(.060)$ & $(.007)$ & $(.004)$ \\
\hline \multirow[t]{2}{*}{ Abortion } & $.006^{* * *}$ & -.002 & .006 & $.006^{* * *}$ & -.003 & .005 \\
\hline & $(.002)$ & $(.004)$ & $(.006)$ & $(.002)$ & $(.004)$ & $(.006)$ \\
\hline \multirow[t]{2}{*}{ Log Relative Wages } & .006 & .009 & $.028^{* * *}$ & .003 & .005 & .006 \\
\hline & $(.005)$ & $(.009)$ & $(.010)$ & $(.005)$ & $(.007)$ & $(.009)$ \\
\hline \multirow[t]{2}{*}{ Cohort Size (in 10,000 s) } & $.001^{* *}$ & .001 & $.005^{* * *}$ & $.001^{* *}$ & .001 & $.005^{* * *}$ \\
\hline & $(.005)$ & $(.001)$ & $(.001)$ & $(.000)$ & $(.001)$ & $(.001)$ \\
\hline Observations & 677,055 & 487,681 & 308,630 & 674,053 & 483,885 & 304,990 \\
\hline
\end{tabular}

This table shows estimates from a probit regression where the dependent variable takes value 1 if the student plans for a career in teaching, and 0 otherwise. The reported coefficients are the marginal effects estimated at the mean of the independent variables.. Standard errors are robust and clustered by state. $*$ indicates $\mathrm{p}<.10,{ }^{* *} \mathrm{p}<.05$, and ${ }^{* * *} \mathrm{p}<.01$. All specifications include controls for high school grades, college selectivity, race, and for being catholic. Furthermore, all specifications control for state, and cohort fixed effects, and state-specific time trends. 
Table A.10: Plans to Teach - Alternative Wage Measures - Women (CIRP Surveys)

\begin{tabular}{|c|c|c|c|c|c|c|}
\hline \multirow{3}{*}{ Independent variable } & \multicolumn{3}{|c|}{ Relative wages: $25-50$ year olds } & \multicolumn{3}{|c|}{ Relative wages: $30-55$ year olds } \\
\hline & (i) & (ii) & (iii) & (iv) & $(\mathrm{v})$ & (vi) \\
\hline & high & medium & low & high & medium & low \\
\hline \multirow[t]{2}{*}{ Union } & -.004 & -.009 & $-.018^{* *}$ & -.003 & -.008 & $-.018^{* *}$ \\
\hline & $(.013)$ & $(.010)$ & $(.008)$ & $(.012)$ & $(.010)$ & $(.008)$ \\
\hline \multirow[t]{2}{*}{ Pill } & .012 & $.016^{*}$ & $.029 * * *$ & .011 & .015 & $.029 * * *$ \\
\hline & $(.011)$ & $(.011)$ & $(.057)$ & $(.011)$ & $(.009)$ & $(.011)$ \\
\hline \multirow[t]{2}{*}{ Abortion } & .009 & -.008 & -.017 & .009 & -.007 & -.016 \\
\hline & $(.006)$ & $(.008)$ & $(.012)$ & $(.007)$ & $(.009)$ & $(.012)$ \\
\hline \multirow[t]{2}{*}{ Log Relative Wages } & $-.019^{*}$ & -.013 & -.003 & -.012 & $-.021^{*}$ & -.010 \\
\hline & $(.010)$ & $(.013)$ & $(.016)$ & $(.008)$ & $(.011)$ & $(.014)$ \\
\hline \multirow[t]{2}{*}{ Cohort Size (in 10,000 s) } & $.002^{* * *}$ & .001 & .001 & $.002^{* * *}$ & .002 & .001 \\
\hline & $(.001)$ & $(.001)$ & $(.003)$ & $(.000)$ & $(.001)$ & $(.003)$ \\
\hline Observations & 728,342 & 490,400 & 202,212 & 727,339 & 489,958 & 201,977 \\
\hline
\end{tabular}

This table shows estimates from a probit regression where the dependent variable takes value 1 if the student plans for a career in teaching, and 0 otherwise. The reported coefficients are the marginal effects estimated at the mean of the independent variables.. Standard errors are robust and clustered by state. $*$ indicates $\mathrm{p}<.10,{ }^{* *} \mathrm{p}<.05$, and ${ }^{* * *} \mathrm{p}<.01$. All specifications include controls for high school grades, college selectivity, race, and for being catholic. Furthermore, all specifications control for state, and cohort fixed effects, and state-specific time trends. 
Table A.11: Plans to Teach: Men (CIRP Surveys)

\begin{tabular}{|c|c|c|c|c|c|}
\hline Independent variable & (i) & (ii) & (iii) & (iv) & $(\mathrm{v})$ \\
\hline \multirow[t]{2}{*}{ Union } & -.004 & - & - & - & - \\
\hline & $(.003)$ & & & & - \\
\hline \multirow[t]{2}{*}{ Pill } & - & -.002 & - & - & - \\
\hline & & $(.005)$ & & & - \\
\hline \multirow[t]{2}{*}{ Abortion } & - & - & $-.004^{* *}$ & - & - \\
\hline & & & $(.002)$ & & - \\
\hline \multirow[t]{2}{*}{ Log Relative Wages } & - & - & - & .009 & - \\
\hline & & & & $(.008)$ & - \\
\hline \multirow[t]{2}{*}{ Cohort Size (in 10,000 s) } & - & - & - & - & .001 \\
\hline & - & - & - & - & $(.001)$ \\
\hline Observations & $1,587,037$ & $1,587,037$ & $1,587,037$ & $1,587,037$ & $1,587,037$ \\
\hline
\end{tabular}

This table shows estimates from a probit regression where the dependent variable takes value 1 if the student plans for a career in teaching, and 0 otherwise. The reported coefficients are the marginal effects estimated at the mean of the independent variables.. Standard errors are robust and clustered by state. ${ }^{*}$ indicates $\mathrm{p}<.10,{ }^{* *} \mathrm{p}<.05$, and ${ }^{* * *} \mathrm{p}<.01$. All specifications include controls for high school grades, college selectivity, race, and for being catholic. Furthermore, all specifications control for state, and cohort fixed effects, and state-specific time trends. 
Table A.12: Plans to Teach: Women (CIRP Surveys)

\begin{tabular}{|c|c|c|c|c|c|}
\hline Independent variable & (i) & (ii) & (iii) & (iv) & $(\mathrm{v})$ \\
\hline \multirow[t]{2}{*}{ Union } & -.009 & - & - & - & - \\
\hline & $(.007)$ & & & & - \\
\hline \multirow[t]{2}{*}{ Pill } & - & $.022^{*}$ & - & - & - \\
\hline & & $(.013)$ & & & - \\
\hline \multirow[t]{2}{*}{ Abortion } & - & - & -.002 & - & - \\
\hline & & & $(.006)$ & & - \\
\hline \multirow[t]{2}{*}{ Log Relative Wages } & - & - & - & $-.022 * *$ & - \\
\hline & & & & $(.011)$ & - \\
\hline \multirow[t]{2}{*}{ Cohort Size (in 10,000s) } & - & - & - & - & .001 \\
\hline & - & - & - & - & $(.001)$ \\
\hline Observations & $1,539,136$ & $1,539,136$ & $1,539,136$ & $1,539,136$ & $1,539,136$ \\
\hline
\end{tabular}

This table shows estimates from a probit regression where the dependent variable takes value 1 if the student plans for a career in teaching, and 0 otherwise. The reported coefficients are the marginal effects estimated at the mean of the independent variables.. Standard errors are robust and clustered by state. ${ }^{*}$ indicates $\mathrm{p}<.10,{ }^{* *} \mathrm{p}<.05$, and ${ }^{* * *} \mathrm{p}<.01$. All specifications include controls for high school grades, college selectivity, race, and for being catholic. Furthermore, all specifications control for state, and cohort fixed effects, and state-specific time trends. 
Table A.13: Other Career Plans - Men (CIRP Surveys)

\begin{tabular}{|c|c|c|c|c|c|c|c|c|c|}
\hline \multirow[b]{2}{*}{ Independent variable } & \multicolumn{3}{|c|}{ Law and Medicine } & \multicolumn{3}{|c|}{ Business } & \multicolumn{3}{|c|}{ Engineering } \\
\hline & $\begin{array}{l}\text { (i) } \\
\text { high }\end{array}$ & $\begin{array}{c}\text { (ii) } \\
\text { medium }\end{array}$ & $\begin{array}{l}\text { (iii) } \\
\text { low }\end{array}$ & $\begin{array}{l}\text { (iv) } \\
\text { high }\end{array}$ & $\begin{array}{c}(\mathrm{v}) \\
\text { medium }\end{array}$ & $\begin{array}{l}\text { (vi) } \\
\text { low }\end{array}$ & $\begin{array}{l}\text { (vii) } \\
\text { high }\end{array}$ & $\begin{array}{c}\text { (viii) } \\
\text { medium }\end{array}$ & $\begin{array}{l}\text { (ix) } \\
\text { low }\end{array}$ \\
\hline Union & $\begin{array}{c}.001 \\
(.009)\end{array}$ & $\begin{array}{l}-.005 \\
(.004)\end{array}$ & $\begin{array}{l}-.001 \\
(.003)\end{array}$ & $\begin{array}{c}.008 \\
(.005)\end{array}$ & $\begin{array}{c}.001 \\
(.008)\end{array}$ & $\begin{array}{c}.004 \\
(.008)\end{array}$ & $\begin{array}{c}.003 \\
(.011)\end{array}$ & $\begin{array}{c}.010 \\
(.012)\end{array}$ & $\begin{array}{l}-.006 \\
(.013)\end{array}$ \\
\hline Pill & $\begin{array}{l}-.012 \\
(.008)\end{array}$ & $\begin{array}{l}-.009^{*} \\
(.006)\end{array}$ & $\begin{array}{l}-.007 \\
(.005)\end{array}$ & $\begin{array}{l}.019^{* *} \\
(.008)\end{array}$ & $\begin{array}{c}.014 \\
(.011)\end{array}$ & $\begin{array}{c}.009 \\
(.008)\end{array}$ & $\begin{array}{l}-.010 \\
(.021)\end{array}$ & $\begin{array}{l}-.008 \\
(.017)\end{array}$ & $\begin{array}{l}-.002 \\
(.013)\end{array}$ \\
\hline Abortion & $\begin{array}{l}-.004 \\
(.005)\end{array}$ & $\begin{array}{c}.004 \\
(.005)\end{array}$ & $\begin{array}{l}-.002 \\
(.004)\end{array}$ & $\begin{array}{l}-.001 \\
(.008)\end{array}$ & $\begin{array}{l}-.012 \\
(.016)\end{array}$ & $\begin{array}{c}-.021^{* *} \\
(.008)\end{array}$ & $\begin{array}{c}-.032^{*} \\
(.016)\end{array}$ & $\begin{array}{l}-.020 \\
(.018)\end{array}$ & $\begin{array}{c}.029 \\
(.010)\end{array}$ \\
\hline Log Relative Wages & $\begin{array}{l}-.008 \\
(.018)\end{array}$ & $\begin{array}{c}.002 \\
(.010)\end{array}$ & $\begin{array}{l}-.002 \\
(.006)\end{array}$ & $\begin{array}{l}.021^{*} \\
(.013)\end{array}$ & $\begin{array}{l}-.018^{*} \\
(.011)\end{array}$ & $\begin{array}{c}-.027^{*} \\
(.014)\end{array}$ & $\begin{array}{l}-.001 \\
(.031)\end{array}$ & $\begin{array}{l}-.008 \\
(.023)\end{array}$ & $\begin{array}{c}-.031^{* *} \\
(.016)\end{array}$ \\
\hline Cohort Size (in 10,000s) & $\begin{array}{c}.003 \\
(.002)\end{array}$ & $\begin{array}{l}.002^{* *} \\
(.001)\end{array}$ & $\begin{array}{c}.000 \\
(.001)\end{array}$ & $\begin{array}{c}.001 \\
(.002)\end{array}$ & $\begin{array}{l}-.002 \\
(.002)\end{array}$ & $\begin{array}{l}-.002 \\
(.003)\end{array}$ & $\begin{array}{l}-.004^{*} \\
(.002)\end{array}$ & $\begin{array}{l}-.000 \\
(.002)\end{array}$ & $\begin{array}{l}.005^{*} \\
(.003)\end{array}$ \\
\hline Observations & 644,349 & 487,797 & 308,752 & 644,349 & 487,797 & 308,752 & 644,349 & 487,797 & 308,752 \\
\hline
\end{tabular}

This table shows estimates from a probit regression where the dependent variable takes value 1 if the student plans for the relevant career, and 0 otherwise. The reported coefficients are the marginal effects estimated at the mean of the independent variables.. Standard errors are robust and clustered by state. ${ }^{*}$ indicates $\mathrm{p}<.10,{ }^{* *} \mathrm{p}<.05$, and ${ }^{* * *} \mathrm{p}<.01$. All specifications include controls for high school grades, college selectivity, race, and for being catholic. Furthermore, all specifications control for state, and cohort fixed effects, and state-specific time trends. 
Table A.14: Other Career Plans - Women (CIRP Surveys)

\begin{tabular}{|c|c|c|c|c|c|c|c|c|c|}
\hline \multirow[b]{2}{*}{ Independent variable } & \multicolumn{3}{|c|}{ Law and Medicine } & \multicolumn{3}{|c|}{ Business } & \multicolumn{3}{|c|}{ Nursing and Clerical } \\
\hline & $\begin{array}{l}\text { (i) } \\
\text { high }\end{array}$ & $\begin{array}{c}\text { (ii) } \\
\text { medium }\end{array}$ & $\begin{array}{l}\text { (iii) } \\
\text { low }\end{array}$ & $\begin{array}{l}\text { (iv) } \\
\text { high }\end{array}$ & $\begin{array}{c}(\mathrm{v}) \\
\text { medium }\end{array}$ & $\begin{array}{l}\text { (vi) } \\
\text { low }\end{array}$ & $\begin{array}{l}\text { (vii) } \\
\text { high }\end{array}$ & $\begin{array}{c}\text { (viii) } \\
\text { medium }\end{array}$ & $\begin{array}{l}\text { (ix) } \\
\text { low }\end{array}$ \\
\hline Union & $\begin{array}{c}.002 \\
(.004)\end{array}$ & $\begin{array}{l}-.000 \\
(.003)\end{array}$ & $\begin{array}{c}.002 \\
(.002)\end{array}$ & $\begin{array}{c}.001 \\
(.003)\end{array}$ & $\begin{array}{c}.001 \\
(.006)\end{array}$ & $\begin{array}{c}.002 \\
(.006)\end{array}$ & $\begin{array}{l}.005 \\
(.007)\end{array}$ & $\begin{array}{c}.010 \\
(.012)\end{array}$ & $\begin{array}{l}-.002 \\
(.010)\end{array}$ \\
\hline Pill & $\begin{array}{l}-.012 \\
(.008)\end{array}$ & $\begin{array}{l}-.002 \\
(.003)\end{array}$ & $\begin{array}{l}-.0073 \\
(.002)\end{array}$ & $\begin{array}{c}.005 \\
(.007)\end{array}$ & $\begin{array}{c}.008 \\
(.006)\end{array}$ & $\begin{array}{c}.007 \\
(.007)\end{array}$ & $\begin{array}{c}.007 \\
(.021)\end{array}$ & $\begin{array}{l}-.008 \\
(.017)\end{array}$ & $\begin{array}{l}-.008 \\
(.014)\end{array}$ \\
\hline Abortion & $\begin{array}{l}-.004 \\
(.004)\end{array}$ & $\begin{array}{c}-.004^{* *} \\
(.002)\end{array}$ & $\begin{array}{c}-.004^{* * *} \\
(.001)\end{array}$ & $\begin{array}{c}.003 \\
(.006)\end{array}$ & $\begin{array}{c}.000 \\
(.007)\end{array}$ & $\begin{array}{c}.001 \\
(.007)\end{array}$ & $\begin{array}{c}.002 \\
(.006)\end{array}$ & $\begin{array}{l}-.020 \\
(.018)\end{array}$ & $\begin{array}{l}.026^{*} \\
(.010)\end{array}$ \\
\hline Log Relative Wages & $\begin{array}{c}.014 \\
(.010)\end{array}$ & $\begin{array}{l}.006^{* *} \\
(.010)\end{array}$ & $\begin{array}{c}.005 \\
(.004)\end{array}$ & $\begin{array}{l}-.009 \\
(.007)\end{array}$ & $\begin{array}{c}.000 \\
(.008)\end{array}$ & $\begin{array}{l}-.003 \\
(.009)\end{array}$ & $\begin{array}{l}.018^{*} \\
(.011)\end{array}$ & $\begin{array}{l}-.008 \\
(.023)\end{array}$ & $\begin{array}{l}-.000 \\
(.015)\end{array}$ \\
\hline Cohort Size (in 10,000s) & $\begin{array}{c}.002^{* * *} \\
(.001)\end{array}$ & $\begin{array}{c}.001 \\
(.001)\end{array}$ & $\begin{array}{l}-.000 \\
(.000)\end{array}$ & $\begin{array}{c}.001^{* * *} \\
(.000)\end{array}$ & $\begin{array}{c}.001 \\
(.001)\end{array}$ & $\begin{array}{c}.000 \\
(.001)\end{array}$ & $\begin{array}{l}-.001 \\
(.002)\end{array}$ & $\begin{array}{l}-.000 \\
(.002)\end{array}$ & $\begin{array}{l}-.001 \\
(.003)\end{array}$ \\
\hline Observations & 728,501 & 490,505 & 202,298 & 728,501 & 490,505 & 202,298 & 728,501 & 490,505 & 202,298 \\
\hline
\end{tabular}

This table shows estimates from a probit regression where the dependent variable takes value 1 if the student plans for the relevant career, and 0 otherwise. The reported coefficients are the marginal effects estimated at the mean of the independent variables.. Standard errors are robust and clustered by state. ${ }^{*}$ indicates $\mathrm{p}<.10,{ }^{* *} \mathrm{p}<.05$, and ${ }^{* * *} \mathrm{p}<.01$. All specifications include controls for high school grades, college selectivity, race, and for being catholic. Furthermore, all specifications control for state, and cohort fixed effects, and state-specific time trends. 